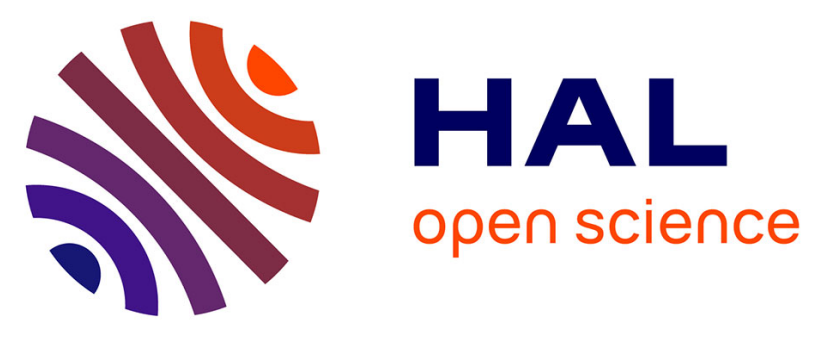

\title{
Revisiting diesel fuel formulation from Petroleum light and middle refinery streams based on optimized engine behavior
}

\author{
Arij Ben Amara, Roland Dauphin, Hassan Babiker, Yoann Viollet, Junseok \\ Chang, Nicolas Jeuland, Amer Amer
}

\section{To cite this version:}

Arij Ben Amara, Roland Dauphin, Hassan Babiker, Yoann Viollet, Junseok Chang, et al.. Revisiting diesel fuel formulation from Petroleum light and middle refinery streams based on optimized engine behavior. Fuel, 2016, 174, pp.63-75. 10.1016/j.fuel.2016.01.062 . hal-01293384

\section{HAL Id: hal-01293384 \\ https://hal.science/hal-01293384}

Submitted on 24 Mar 2016

HAL is a multi-disciplinary open access archive for the deposit and dissemination of scientific research documents, whether they are published or not. The documents may come from teaching and research institutions in France or abroad, or from public or private research centers.
L'archive ouverte pluridisciplinaire HAL, est destinée au dépôt et à la diffusion de documents scientifiques de niveau recherche, publiés ou non, émanant des établissements d'enseignement et de recherche français ou étrangers, des laboratoires publics ou privés. 


\section{Revisiting diesel fuel formulation from Petroleum light and middle}

\section{2 refinery streams based on optimized engine behavior}

3 Arij Ben Amara ${ }^{1}$, Roland Dauphin ${ }^{1}$, Hassan Babiker ${ }^{2}$, Yoann Viollet ${ }^{2}$, Junseok Chang ${ }^{2}$, Nicolas

4 Jeuland $^{1,3}$, Amer Amer ${ }^{2}$

$5 \quad{ }^{1}$ IFP Energies Nouvelles, 1-4 avenue de Bois-Préau 92852 Rueil-Malmaison Cedex, France

$6 \quad 2$ Saudi Aramco, R\&D Center, PO Box 62, Dhahran 31311, Saudi Arabia

$7 \quad{ }^{3}$ Present address: Safran Tech, Paris-Saclay, France

$8 *$ Corresponding author

9 Contact: arij.ben-amara@ifpen.fr

10 Abstract

11 The share of diesel fuel in European transport sector, which currently represents over $50 \%$ of total

12 demand, is increasing, requiring massive imports of this product, while at the same time, gasoline fuels are

13 today in surplus. In terms of air pollutant emissions, gasoline and kerosene streams have shown potential

14 in achieving lower emissions in Compression Ignition (CI) engines, particularly nitrogen oxides (NOx)

15 and particulates. A new fuel formulation approach through the use of light fractions within diesel

16 technology could consequently address both questions of energy demand balance and reduction of diesel

17 engines pollution footprint. In this study, a fuel formulation for a Diesel engine is optimized to achieve

18 lower pollutants emissions and higher engine efficiency. The fuel matrix is based on seven refinery

19 streams representative of gasoline (Hydrotreated Straight-Run Gasoline HSRG, Hydrotreated Fluid

20 Catalytic Cracking HFCC and Reformate REF), kerosene (Hydrotreated Straight-Run Kerosene HSRK

21 and Hydrocracked Kerosene HCKK) and diesel cuts (Hydrotreated Straight-Run Diesel HSRD and

22 Hydrocracked Light Diesel HCKLD). A D-Optimal mixture design is applied to build, a 12-run, 7-factor 
23 fuel matrix and the fuels are thoroughly optimized on two engine conditions at light and mid-load 24 representative of typical vehicle running conditions. The results show a high sensitivity and a good 25 correlation of the engine efficiency and pollutants emissions with the volumetric contribution of each 26 refinery stream to the fuel composition. The optimum fuel composition varies across the range of engine 27 operating points. At light load for example, the addition of up to $50 \% \mathrm{v}$ of gasoline streams (HSRG and 28 HFCC) to diesel streams demonstrates a good potential to simultaneously reduce NOx and particulate

29 emissions and an overall good engine performance. Reformate, a highly aromatic gasoline stream, did not 30 offer an advantage at any of the tested conditions due to high particulate emissions. The two kerosene 31 streams perform similarly to diesel streams in terms of engine efficiency and pollutants emissions. A 32 compromise fuel, composed of 50\%v HSRG and 50\%v HSRD, is proposed that allowed halving NOx and 33 particulate emissions and reducing the fuel consumption by 5\%wt compared to reference diesel HSRD.

34 The optimized fuel represents an alternative for balancing diesel and gasoline demand and for pollutant 35 emissions reduction.

\section{Keywords}

37 Naphtha, Straight-Run Gasoline, Design of Experiment DoE, formulation, optimization, pollutants, 38 efficiency, NOx, particulates. 


\section{$44 \quad 1$ Introduction}

45 Energy and environmental concerns are driving several changes in the European transport sector, with

46 increasing incentives towards alternative renewable energy sources and new refining processes. However,

47 conventional fossil fuels remain the sector's major energy source. Conventional liquid fuels represented

$4895 \%$ of European demand in 2012 [1] and according to recent forecasts from the European Commission,

49 are likely to remain dominant over the coming decades [2]. For transport applications, the share of diesel

50 fuel represents over $50 \%$ of the European market (in comparison with gasoline and jet fuel, 32\% and 14\%

51 respectively) and demand is rising [2]. The main drivers for such high demand are the high efficiency of

52 diesel engines and recent improvements of after-treatment systems, noise and drivability. Conversely,

53 light products like gasoline cuts, issuing from straight run distillation or Fluid Catalytic Cracking (FCC), a

54 conversion process widely used in European refineries, are today in surplus. This has drawn much

55 attention to their use as an alternative fuel in diesel engines to balance the energy demand and to meet

56 future pollutant emissions legislation. To achieve pollutant targets for light duty diesel engines, several

57 technological solutions are used to enhance the control of ignition timing and combustion rate [3]

58 including variable compression ratio, adapted injection systems, improved piston geometry, increased

59 exhaust gas recirculation (EGR) rates, and improved cooling or boosting capacity [4],[5],[6],[7]. However,

60 the physical and chemical characteristics of a fuel can have an important impact on mixture formation,

61 ignition and heat release rate [8],[9]. Higher volatility enhances the mixture formation during the ignition

62 delay and a lower cetane number delays the ignition occurrence, mainly at low-to-mid loads [10].

63 Increasing fuel volatility in fuels of similar chemical composition has shown a soot reduction potential in

64 CI engines for diesel and kerosene cuts due to the reduction of over-rich areas, and a moderate effect for

65 gasoline cuts [11]. Increasing diesel volatility at equal cetane number [12] leads to a reduction of liquid

66 film formation on cylinder walls, and thus, a reduction in smoke and enhanced fuel-conversion efficiency.

67 The application of highly mixed combustion modes however presents the disadvantage of a load range

68 limited by difficult combustion control at high load and an increase in $\mathrm{HC}$ and $\mathrm{CO}$ due to lower 
combustion efficiency [7]. Fuel wall impingement, the crevices, boundary layers, and fuel-lean regions

70 formed during longer auto-ignition delay may constitute additional sources of HC and CO emissions [13], $71 \quad[14],[15]$.

\section{Petroleum-based formulations for Diesel engines and impacts on pollutants}

73 The use of gasoline or kerosene as alternatives to diesel fuel has been studied by several groups for their 74 pollutants reducing potential. Han et al. [16] proved a simultaneous reduction of NOx and soot emissions 75 using up to $40 \%$ gasoline with low EGR requirement compared to diesel fuel. CO and $\mathrm{HC}$ emissions were 76 comparable to diesel engines at light loads, however increased at high loads [17]. Kerosene fuels are also 77 attractive for their higher volatility and lower cetane number, generally between EU diesel and gasoline.

78 Tested alone in compression ignition engines, kerosene presents lower NOx emissions than diesel at a 79 similar soot level [18] [19] and in mixture with diesel, it enhances the combustion efficiency [20]. The 80 chemical effect of fuel formulation is difficult to separate from the physical effect, especially in complex 81 engine configurations. Nevertheless, several general trends have been put forward in recent literature.

82 Most usually, fuels containing high level of aromatics increase soot formation [10] [21]. Diminishing the

83 aromatic content generally correlates with particulate reduction for diesel, gasoline and kerosene 84 distillation cuts [11]. Paraffinic saturated fuels have, in comparison, lower soot tendency regardless of 85 their molecular structure [22] [23]. Note however, the exception of fuels containing a high proportion of 86 long-chain normal paraffins, which may lead to enhanced soot formation through increasing fuel 87 ignitability and the creation of local rich areas [21]. Unsaturated hydrocarbons, namely, monoaromatics 88 and short-chain olefins, can lead to over 2 and 5 folds higher NOx tendency respectively when compared 89 to paraffinic saturated compounds [24]. Aromatic-rich fuels can have longer ignition delay times but can 90 also form higher level of NOx towards the end of the combustion [25]. The safety question related to 91 lighter fractions introduction in Diesel fuels has been recently addressed by Al-Abdullah et al. [26] where 92 the flash points (FP) and volatilities of blends of a commercial diesel and a commercial gasoline were 93 measured. According to their results, the flash point decreases as the concentration of gasoline is 
94 increased. For a mixture of $16 \%$ vol of gasoline in diesel, FP reaches $40^{\circ} \mathrm{C}$. These results suggest that

95 blends with high gasoline fractions should present very similar behavior compared with gasoline which 96 has a $\mathrm{FP}$ of $45^{\circ} \mathrm{C}$.

\section{Modeling approaches for fuel design}

98 Optimizing a fuel's formulation for advanced combustion modes requires an accurate knowledge of the

99 fuel's behavior over a wide range of engine operating conditions, both in steady state and transient modes.

100 To better address these complex physical and chemical phenomena involved, statistical modeling 101 approaches can represent powerful tools. Especially, Design of Experiments (DoE), refers to the process 102 of planning, designing and analyzing the experiments. It involves the development of statistical relations 103 between the response variables and the input factors and their interactions. In engine applications, DoE 104 have been widely applied in engine optimization processes [27]. DoE has also been used to optimize fuel 105 properties in terms of cetane number $(\mathrm{CN})$, volatility and total aromatics content [28]. However, to our 106 knowledge, few studies have used DoE to optimize the fuel formulation with regards to combustion 107 behavior. In this study, we propose to evaluate a DoE approach to optimize fuel formulation for diesel 108 engines based on existing refinery streams, to improve engine efficiency and reduce main pollutant 109 emissions. Engine outputs were modeled as a function of the fuel composition and an optimum fuel is 110 proposed.

\section{2. Materials and methods}

112 Figure 1 presents the layout of the present study: first, seven refinery streams used in road and air 113 transport were selected. A 12-run, 7-factor D-Optimal mixture design was then generated using Design-

114 Expert ${ }^{\circledR}$ version 9. The seven refinery streams constitute the design variables while engine outputs 115 correspond to the response parameters. Engine outputs were then modeled by first order models with 116 regards to the volume fraction of the streams and the models presenting good quality were used to 117 determine an optimum fuel composition. 
118

\section{Refinery streams}

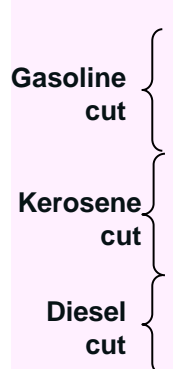
cut
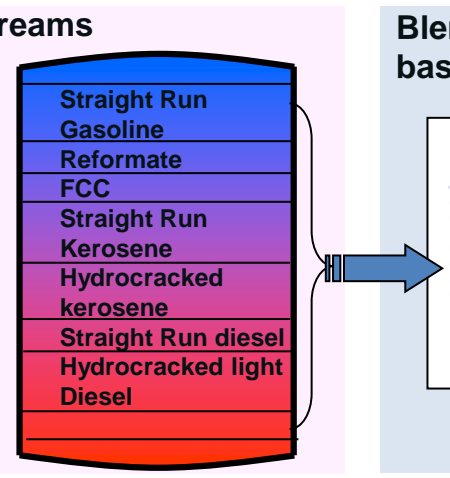

Blending Fuel Matrix based on DoE

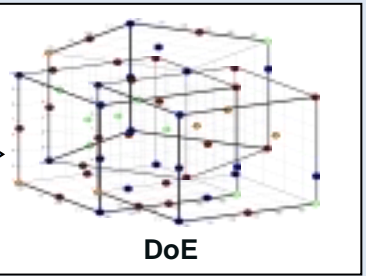

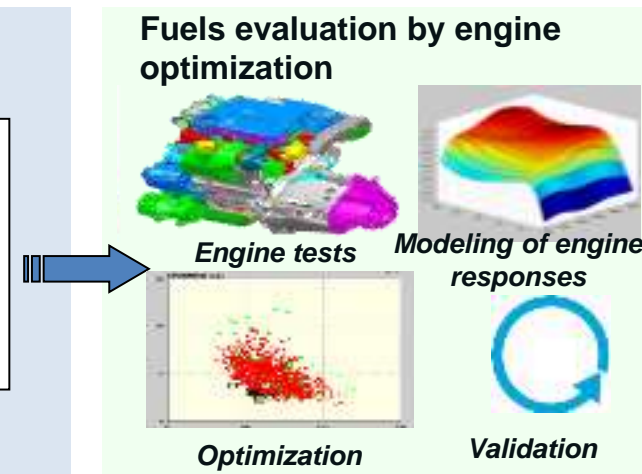

Figure 1: Scheme of the study outline

\subsection{Refinery streams}

Seven refinery streams representative of gasoline, kerosene and diesel cuts were selected involving three straight-run streams: Hydrotreated Straight Run Gasoline, Kerosene and Diesel, noted, HSRG, HSRK, HSRD, respectively. Main streams properties are presented in Figure 2. Hydrocracked kerosene (HCKK) and light diesel (HCKLD), Hydrotreated Fluid Catalytic Cracking (HFCC) chosen for its high olefins content (near 45\%wt) and reformate (REF) constituted of over $97 \% \mathrm{wt}$ aromatics were selected as the remaining four streams. REF and HSRD were supplied by Coryton Advanced Fuels, and the remaining streams were provided by various Saudi Arabian refineries. All streams have a sulfur content below 10 ppm, except for HSRK which contains 220 ppm (the detailed composition of sulfur containing species were not determined during this work), and they cover a broad distillation range from $35^{\circ} \mathrm{C}$ to $380^{\circ} \mathrm{C}$. Initial Boiling Points vary from $35^{\circ} \mathrm{C}$ to $188^{\circ} \mathrm{C}$ and Final Points from $115^{\circ} \mathrm{C}$ to $380^{\circ} \mathrm{C}$. Stream densities vary from 692 to $868 \mathrm{~kg} / \mathrm{m} 3$ and kinematic viscosity from 0.36 to $3.3 \mathrm{~mm}^{2} / \mathrm{s}$. Gasoline and kerosene streams have lower values of density and viscosity compared to diesel streams. Paraffins-OlefinsNaphthenes-Aromatics (PONA) composition was determined by gas chromatography mass spectrometry GC-MS analysis and the most paraffinic fuels are the HSRG and HSRK, while naphthenes are the highest in hydrocracked streams (up to $40 \% \mathrm{wt}$ ). REF is composed of over $97 \% \mathrm{wt}$ aromatics mainly branched monoaromatics (toluene and xylenes), followed by HSRD $(45 \% \mathrm{wt})$ which has the highest yield of polyaromatics $(3.6 \% \mathrm{wt})$. Olefins are present exclusively in HFCC at $45 \% \mathrm{wt}$. The cetane number was 

assessed by CFR technique except for REF and HFCC whose cetane was evaluated by a blending method.

139 The $\mathrm{CN}$ of the streams ranges from 6 to 55. Detailed analysis of the streams is provided in Appendix A.

Density at $15^{\circ} \mathrm{C}$ ASTM D4052

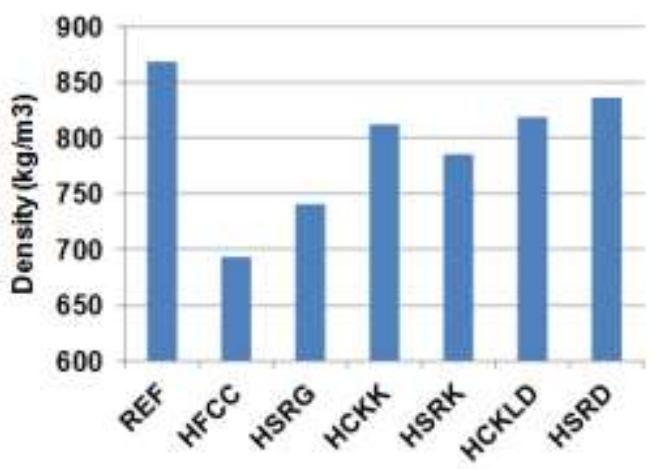

Cetane number

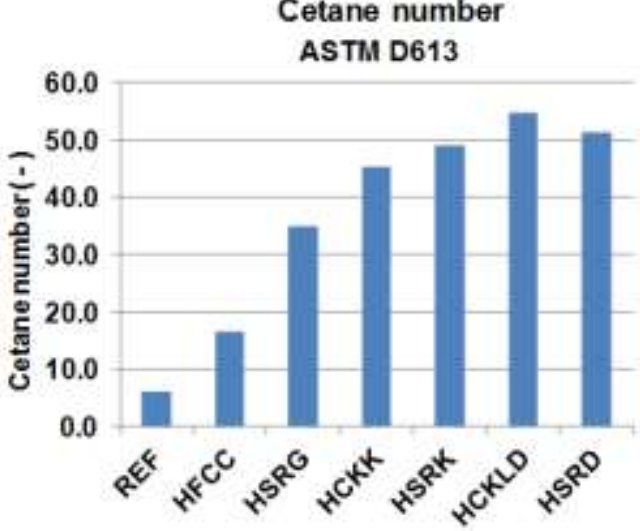

Viscosity at $40^{\circ} \mathrm{C}$ EN ISO3105

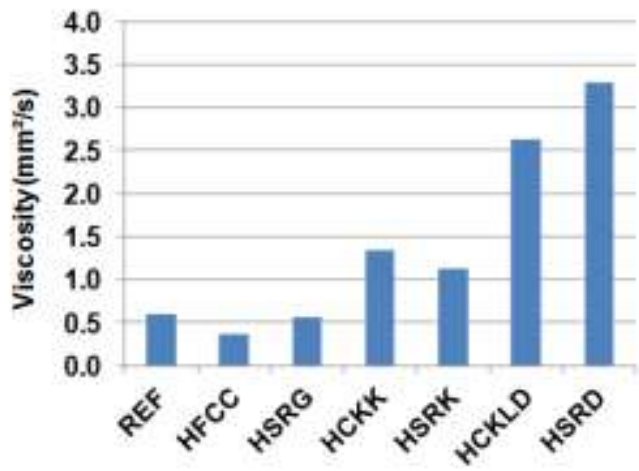

Chemical composition - ASTM D 2425-80

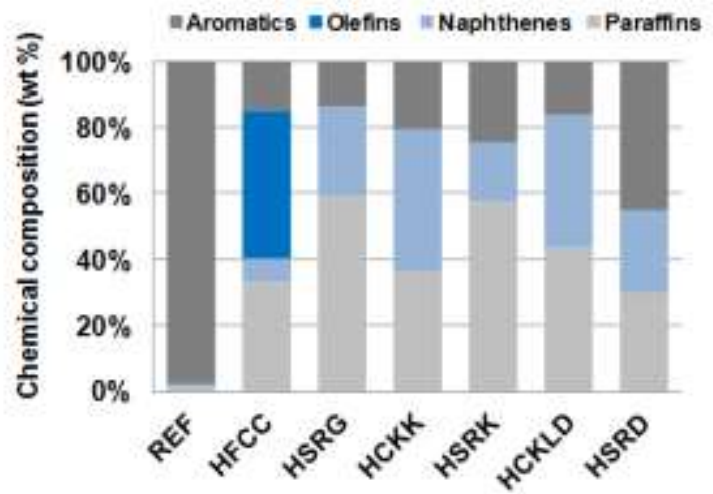

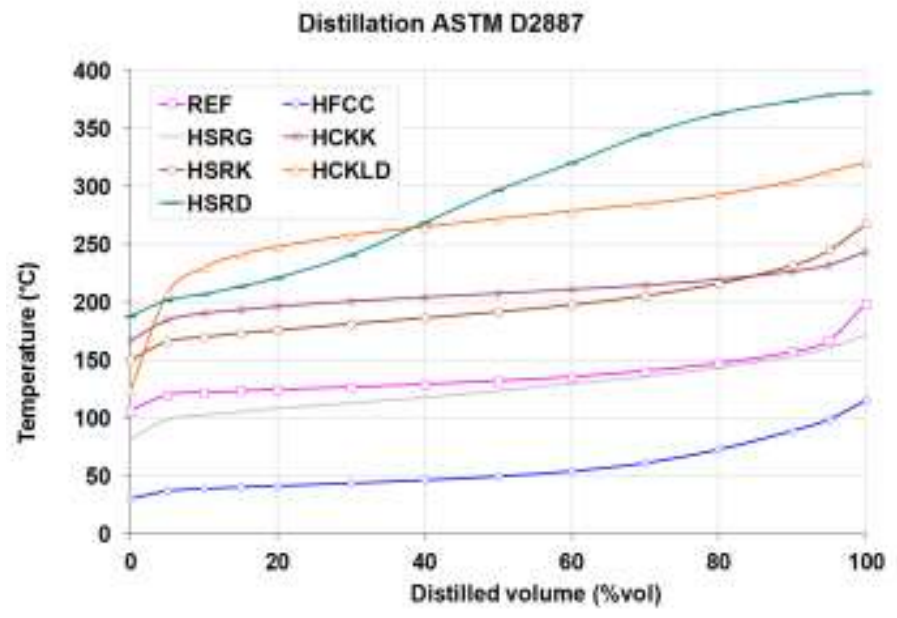

Figure 2: Main fuel properties of the seven selected refinery streams 


\subsection{Fuel matrix definition by Design of Experiment approach}

144 To optimize fuel composition, a 12-run, 7-factor D-Optimal mixture design was generated using Design145 Expert ${ }^{\circledR}$ version 9 [29]. The seven refinery streams constituted the design variables while the engine 146 outputs corresponded to the response parameters. Statistical first-order linear models with no interaction 147 were defined and the matrix was built under constraints of the domain limits. Those limits consisted of the 148 range of cetane number, fractions of diesel, gasoline and kerosene cuts and maximum total aromatics. 149 Hence, the $\mathrm{CN}$ range was defined from 35 to $51(+/-2)$. The upper limit corresponds to current European 150 diesel specification, and the lower was set to reduce the risk of combustion instability at light load based 151 on previous studies from our group [5]. The proportion of gasoline and kerosene streams was allowed up 152 to $50 \%$ vol for each [11] [17] [16] [30], and a minimum of $30 \% \mathrm{vol}$ of diesel streams was required to allow 153 for high load performance and a sufficient viscosity [5]. In addition, total aromatic content was capped at $15450 \%$ to limit smoke emissions. The matrix design was composed of 12 (Fuels 1-12) ranked in order of 155 decreasing cetane number. These fuels included a reference diesel fuel (Fuel 4), binary blends of 156 diesel/kerosene streams (Fuel 1 and 2), binary blends of diesel/gasoline streams: Fuels 3 and 12 containing $1577 \%$ vol and 41\%vol Reformate, Fuels 5 and 6 containing 50\%vol HSRG and Fuels $10-11$ containing 50\% 158 HFCC. Two ternary blends of diesel/kerosene/gasoline streams (Fuels 8-9) and a central point (Fuel 7) 159 composed of all tested streams was set as repeatability point and tested 8 times throughout the study 160 (Table 1). Finally, a validation fuel was also formulated (Fuel 13) composed of 50\%HCKK, 30\%HSRD and $20 \%$ HSRG. The matrix is detailed in Table 1 . The fuels' properties cover a wide range of physical and chemical properties, some of which were outside the limits of European diesel fuel specifications

163 EN590, especially in terms of density and viscosity. The fuels were treated with lubricity additive

164 (OLI9000 from Innospec) and antioxidant additive (Butylated HydroxyToluene - BHT) to ensure 165 mechanical component durability and a consistent fuel quality throughout the study. 
Table 1: Fuel matrix: Fuel 1-12, Fuel 7 corresponds to the central fuel and was tested 8 times throughout the study, Fuel 13 is the validation fuel (used for models validation)

\begin{tabular}{|c|c|c|c|c|c|c|c|c|c|c|c|c|c|c|c|}
\hline & & Unit & $\begin{array}{c}\text { Fuel } \\
1\end{array}$ & $\begin{array}{c}\text { Fuel } \\
2 \\
\end{array}$ & $\begin{array}{c}\text { Fuel } \\
3\end{array}$ & $\begin{array}{c}\text { Fuel } \\
4\end{array}$ & $\begin{array}{l}\text { Fuel } \\
5\end{array}$ & $\begin{array}{c}\text { Fuel } \\
6\end{array}$ & $\begin{array}{c}\text { Fuel } \\
7\end{array}$ & $\begin{array}{c}\text { Fuel } \\
8 \\
\end{array}$ & \begin{tabular}{|c} 
Fuel \\
9 \\
\end{tabular} & $\begin{array}{c}\text { Fuel } \\
10\end{array}$ & $\begin{array}{c}\text { Fuel } \\
11 \\
\end{array}$ & $\begin{array}{c}\text { Fuel } \\
12 \\
\end{array}$ & $\begin{array}{c}\text { Fuel } \\
13\end{array}$ \\
\hline \multirow[t]{7}{*}{$\begin{array}{l}\text { Stream } \\
\text { composition }\end{array}$} & HSRG & \%vol & 0.0 & 0.0 & 0.0 & 0.0 & 50.0 & 50.0 & 9.7 & 0.0 & 0.0 & 0.0 & 0.0 & 0.0 & 20.0 \\
\hline & HFCC & $\%$ vol & 0.0 & 1.7 & 0.0 & 0.0 & 0.0 & 0.0 & 11.6 & 0.0 & 0.0 & 46.9 & 50.0 & 0.0 & 0.0 \\
\hline & REF & $\%$ vol & 0.0 & 0.0 & 7.4 & 0.0 & 0.0 & 0.0 & 11.3 & 20.0 & 20.0 & 0.0 & 0.0 & 40.8 & 0.0 \\
\hline & HSRK & $\%$ vol & 0.0 & 50.0 & 0.0 & 0.0 & 0.0 & 0.0 & 13.4 & 50.0 & 0.0 & 0.0 & 0.0 & 0.0 & 0.0 \\
\hline & HCKK & \%vol & 50.0 & 0.0 & 0.0 & 0.0 & 0.0 & 0.0 & 11.9 & 0.0 & 50.0 & 0.0 & 0.0 & 0.0 & 50.0 \\
\hline & HSRD & $\%$ vol & 0.0 & 0.0 & 0.0 & 100.0 & 0.0 & 50.0 & 19.8 & 30.0 & 30.0 & 53.1 & 0.0 & 0.0 & 30.0 \\
\hline & HCKLD & $\%$ vol & 50.0 & 48.3 & 92.6 & 0.0 & 50.0 & 0.0 & 22.3 & 0.0 & 0.0 & 0.0 & 50.0 & 59.2 & 0.0 \\
\hline Analyses & Method & Unit & & & & & & & & & & & & & \\
\hline $\begin{array}{l}\text { Density at } \\
15^{\circ} \mathrm{C}\end{array}$ & $\begin{array}{l}\text { ASTM } \\
\text { D4052 } \\
\end{array}$ & \begin{tabular}{|l}
$\mathrm{kg} / \mathrm{m}$ \\
3 \\
\end{tabular} & 815.6 & 801.5 & 822 & 836.6 & 781.4 & $\mid 790.7$ & 802.3 & 817.4 & 829.8 & 777.1 & 763.1 & 837.2 & 806 \\
\hline $\begin{array}{l}\text { Kin.viscosity } \\
40^{\circ} \mathrm{C}\end{array}$ & $\begin{array}{l}\text { EN } \\
\text { ISO310 } \\
5\end{array}$ & $\begin{array}{l}\mathrm{mm}^{2} / \\
\mathrm{s}\end{array}$ & 1.85 & 1.55 & 2.11 & 3.297 & 1.12 & 1.21 & 0.99 & 1.31 & 1.36 & 0.68 & 0.69 & 1.33 & 1.33 \\
\hline Sulfur & $\begin{array}{l}\text { EN ISO } \\
20846 \\
\end{array}$ & $\begin{array}{l}\mathrm{mg} / \mathrm{k} \\
\mathrm{g}\end{array}$ & 1 & 111 & 1 & 2 & 1 & 1 & 31 & 111 & 1 & 3 & 3 & 1 & 1 \\
\hline LHV & $\begin{array}{l}\text { ASTM } \\
\text { D240 } \\
\end{array}$ & $\begin{array}{l}\mathrm{MJ} / \mathrm{k} \\
\mathrm{g} \\
\end{array}$ & 42.97 & 43.29 & 43.13 & 41.83 & 41.22 & 42.79 & 42.12 & 42.29 & 42.65 & 40.12 & 40.20 & 41.95 & 42.67 \\
\hline CN (CFR) & \begin{tabular}{|l} 
ASTM \\
D613 \\
\end{tabular} & - & 52.0 & 51.6 & 51.6 & 51.2 & 46.1 & 46.1 & 41.4 & 41.1 & 40.0 & 38.8 & 36.7 & 35.2 & 47.7 \\
\hline \multicolumn{16}{|l|}{$\mathrm{H} / \mathrm{C} / \mathrm{N} / \mathrm{O}$} \\
\hline $\mathrm{C}$ & & $\% w t$ & 86.08 & 85.90 & 86.32 & 86.25 & 85.68 & 85.81 & 86.48 & 86.89 & 87.07 & 86.08 & 85.94 & 87.84 & 86.04 \\
\hline $\mathrm{H}$ & & $\% w t$ & 13.76 & 13.95 & 13.47 & 13.75 & 14.21 & 14.19 & 13.44 & 13.06 & 12.88 & 13.91 & 13.95 & 12.02 & 13.91 \\
\hline $\mathrm{N}$ & & $\% w t$ & 0.06 & 0.10 & 0.11 & 0.00 & 0.06 & 0.00 & 0.04 & 0.05 & 0.00 & 0.00 & 0.06 & 0.07 & 0.00 \\
\hline 0 & & \%wt & 0.11 & 0.05 & 0.10 & 0.00 & 0.06 & 0.00 & 0.04 & 0.00 & 0.06 & 0.00 & 0.06 & 0.07 & 0.06 \\
\hline $\mathrm{H} / \mathrm{C}$ & & $\% w t$ & 1.92 & 1.95 & 1.87 & 1.91 & 1.99 & 1.98 & 1.87 & 1.80 & 1.77 & 1.94 & 1.95 & 1.64 & 1.94 \\
\hline Composition & GCxGC & & & & & & & & & & & & & & \\
\hline Paraffins & & $\% w t$ & 39.9 & 50.0 & 40.2 & 29.9 & 50.8 & 43.6 & 36.9 & 37.1 & 27.2 & 31.3 & 38.7 & 26.0 & 38.5 \\
\hline Naphtenes & & \%wt & 41.6 & 29.0 & 37.1 & 24.6 & 34.0 & 25.8 & 25.0 & 16.5 & 28.5 & 17.2 & 25.0 & 23.3 & 34.4 \\
\hline Olefins & & $\% w t$ & 0.0 & 0.7 & 0.0 & 0.0 & 0.0 & 0.0 & 4.5 & 0.0 & 0.0 & 19.0 & 20.6 & 0.1 & 0.0 \\
\hline $\begin{array}{l}\text { Monoaromatic } \\
\mathrm{s}\end{array}$ & & \%wt & 17.1 & 18.9 & 21.1 & 41.7 & 14.3 & 28.7 & 32.0 & 44.5 & 42.4 & 30.5 & 14.8 & 49.4 & 25.4 \\
\hline Polyaromatics & & $\% w t$ & 1.5 & 1.3 & 1.6 & 3.6 & 0.9 & 1.8 & 1.5 & 1.7 & 1.8 & 1.9 & 0.9 & 1.3 & 1.7 \\
\hline $\begin{array}{l}\text { Total } \\
\text { Aromatics } \\
\end{array}$ & & $\% w t$ & 18.5 & 20.3 & 22.7 & 45.3 & 15.2 & 30.5 & 33.5 & 46.3 & 44.2 & 32.4 & 15.7 & 50.7 & 27.1 \\
\hline Distillation & \begin{tabular}{|l} 
ASTM \\
D2887 \\
\end{tabular} & & & & & & & & & & & & & & \\
\hline IBP & & ${ }^{\circ} \mathrm{C}$ & 161 & 36 & 129 & 202 & 99 & 98 & 36 & 130 & 130 & 36 & 36 & 125 & 98 \\
\hline T50 & & ${ }^{\circ} \mathrm{C}$ & 233 & 231 & 267 & 292 & 190 & 197 & 201 & 197 & 205 & 197 & 201 & 212 & 208 \\
\hline T95 & & ${ }^{\circ} \mathrm{C}$ & 306 & 326 & 314 & 380 & 306 & 375 & 382 & 369 & 369 & 401 & 328 & 307 & 353 \\
\hline
\end{tabular}

169

170 Figure 3 illustrates the density, viscosity, cetane number and PONA composition of the fuels in the matrix.

171 Diesel-rich and reformate-rich fuels (Fuel 3, 4, 8, 9 and 12) have the higher density, while the lowest 
172 density ones have higher fraction of HSRG and HFCC gasoline streams. Several matrix fuels are under the

173 range of the European specification EN590 (820-845 g/L). Due to the high volatility of several fuels,

174 viscosity could not be measured in the standard $40^{\circ} \mathrm{C}$ temperature. Pedersen model [31] (validated at $10^{\circ} \mathrm{C}$

175 with a correlation coefficient of 0.93 ) was used to estimate viscosity at $40^{\circ} \mathrm{C}$. Calculated viscosity at $40^{\circ} \mathrm{C}$

176 is significantly low for the entire matrix compared with European specification EN 590, except for diesel-

177 rich fuels.

Density at $15^{\circ} \mathrm{C}-\mathrm{ASTM}$ D4052

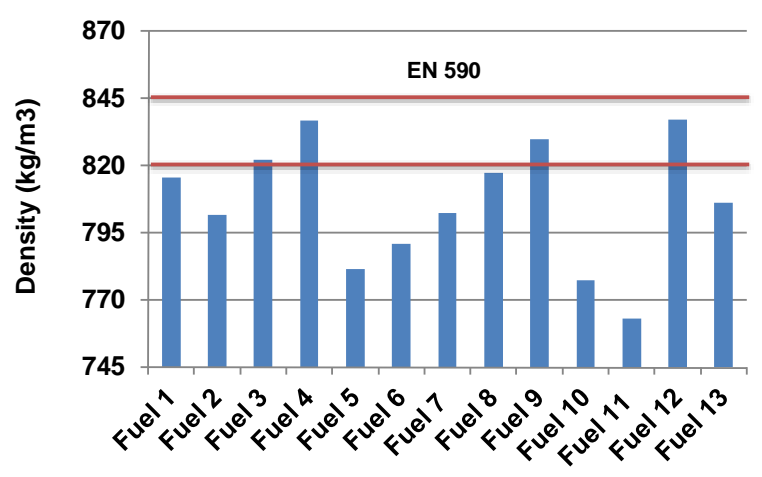

Cetane number

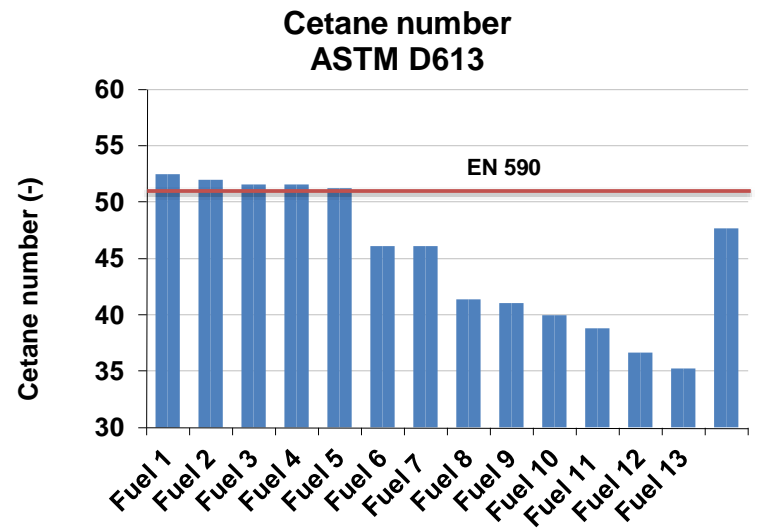

Viscosity at $40^{\circ} \mathrm{C}$ - Pedersen Model

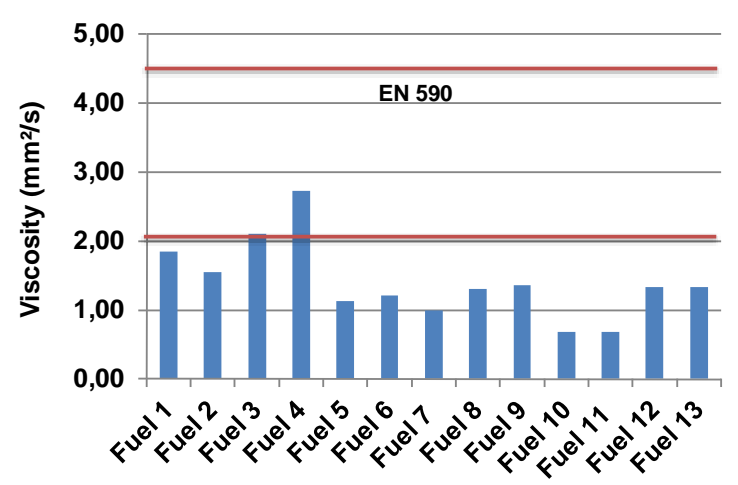

Chemical composition ASTM D 2425-80

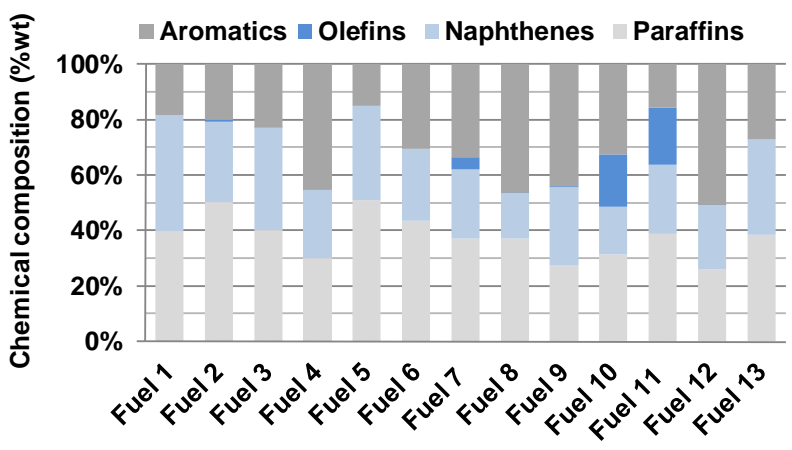

Figure 3: Density, Viscosity at $40^{\circ} \mathrm{C}$ (Pedersen model), cetane number and chemical composition of the fuel matrix Fuels 1-12 and the validation fuel (Fuel 13)

181 PONA composition of the matrix fuels was calculated by linear correlation from the data of single streams

182 (Appendix A). Paraffinic compounds (linear and branched) vary from 26 to 51\%wt. Aromatics range from

18315 to $51 \% w t$. Olefins are present in HFCC containing fuels: i.e. Fuels 2, 7, 10 and 11 . They range from 2

184 to $21 \%$ wt. Finally, naphthenes range from 16 to $42 \%$ wt. Volatility is the highest for Fuels 2,10 and 11 , 

HCKLD whose IBP is close to gasoline streams.

\subsection{Fuel optimization procedure}

188 The experiments were conducted in a DV6D 4-cylinder light duty diesel engine from PSA Peugeot 189 Citroën (PSA), compliant with Euro 5 specification. The engine details are given in Table 2. The engine 190 oil and water temperatures were set to $90^{\circ} \mathrm{C}$ during the experiment. The engine was equipped with a 191 Bosch CRI2.2 common rail direct fuel injection with a maximum rail pressure of 1800 bar, a turbocharger 192 with a fixed geometry and a high pressure EGR system. The engine was tested without the after-treatment 193 system fitted and an open Engine Control Unit (ECU) was used to monitor injection parameters and 194 air/EGR settings.

\begin{tabular}{|c|c|}
\hline Engine specifications & Value \\
\hline Bore & $75 \mathrm{~mm}$ \\
\hline Stroke & $88,3 \mathrm{~mm}$ \\
\hline Displacement & $1560 \mathrm{~cm} 3$ \\
\hline Connecting rod length & $136,8 \mathrm{~mm}$ \\
\hline Compression ratio & $16: 1$ \\
\hline Intake valve opening & $377^{\circ} \mathrm{CA}$ \\
\hline Intake valve closing & $550^{\circ} \mathrm{CA}$ \\
\hline Intake valve maximum lift & $9,25 \mathrm{~mm}$ \\
\hline Exhaust valve opening & $164^{\circ} \mathrm{CA}$ \\
\hline Exhaust valve closing & $350^{\circ} \mathrm{CA}$ \\
\hline Exhaust valve maximum lift & $9,25 \mathrm{~mm}$ \\
\hline Maximum torque & $230 \mathrm{Nm}$ at $1750 \mathrm{rpm}$ \\
\hline Maximum Power & $68 \mathrm{~kW}$ at $4000 \mathrm{rpm}$ \\
\hline
\end{tabular}


The experiment was conducted in double injection mode (i.e. pilot and main injection) with EGR. To cope with the high dispersion of fuels properties, particularly volatility and reactivity, the engine settings were adapted for each fuel. Matrix fuels were optimized separately on six operating points ranging from 1350 to $2400 \mathrm{rpm}$ engine speed and from 1 to 13.4 bar of Brake Mean Effective Pressure (BMEP). These operating points are representative of the New European Driving Cycle (NEDC) and have been used to evaluate new formulation or engine concepts for reduced pollutants emissions by other groups [32], [9]. To better illustrate the main results, we present in this article two engine operating points selected in the light and middle load; $1500 \mathrm{rpm}-6$ bar (EP1) and $2280 \mathrm{rpm}-8.2 \mathrm{bar}$ (EP2). Both engine operating points are optimized using the same methodology for each fuel, allowing the definition successively of the optimum settings of main and pilot injections phasing, pilot quantity, EGR rate and rail pressure. The intake pressure was fixed to PSA's standard calibration matching the maximum engine capacity. Pilot quantity was fixed to $1.5 \mathrm{mg} / \mathrm{stroke}$, corresponding to the average pilot quantity used in the stock calibration. To reduce the optimization time, the fuels were categorized into three cetane ranges (Group 1: 47-52, Group 2: 41-46 and Group 3: 35-40). Within each range, a "central" fuel was defined: Fuel 4, Fuel 7 and Fuel 11, respectively. Central fuels were optimized with a detailed method consisting of successive single parametric variations of main and pilot injection phasing, rail pressure and EGR rate. The optimum parameters are defined to achieve targets of NOx, PM, noise, $\mathrm{CO}, \mathrm{HC}$ and IMEP stability (summarized in

214 final optimized heat release profile was used as a baseline for the optimization of the fuels belonging to 215 the same cetane group. An overview of both methodologies is provided in Figure 4. Note that the injection 216 pressure was optimized for each fuel separately. The initial rail pressure for the "central" fuels (used in the 217 optimization methodology) was that of the standard map, i.e. 800 bar for EP1 and 1146 bar for EP2, while, 218 for the fuels belonging to the same cetane group, the initial rail pressure corresponds to the optimized 219 pressure of the "central" fuel. It should be noted that fixed engine settings such as the intake pressure 220 correspond to diesel like-fuels, and may influence the results of high volatility and low-cetane number 221 fuels. For example, a higher intake may better highlight the potential of high volatility and low-cetane 
222 number fuels according to previous work of Han et al. [17]. Further details on the optimization 223 methodology are provided in Appendix B.

224 Table 3: Engine optimization criteria at $1500 \mathrm{rpm}-6 \mathrm{bar}$ (EP1) and $2280 \mathrm{rpm}-8.2 \mathrm{bar}$ (EP 2). (*) Fuel consumption is minimized if the pollutant targets are respected

\begin{tabular}{|c|c|c|c|c|}
\hline \multirow{2}{*}{ Parameter } & Unit & Precision & \multicolumn{2}{|c|}{$\begin{array}{c}\text { Fixed settings and optimization } \\
\text { criteria }\end{array}$} \\
\hline Engine speed & rpm & $+/-3$ & 1500 & 2280 \\
\hline Engine load & bar & $+/-0.1$ & 6 & 8.2 \\
\hline Intake pressure & bar & $+/-0.015$ & 1.03 & 1.46 \\
\hline NOx & $\mathrm{g} / \mathrm{kWh}$ & $+/-0.03$ & Minimize & Minimize \\
\hline Particles & $\mathrm{g} / \mathrm{kWh}$ & $+/-0.03$ & $<0.15$ & $<0.2$ \\
\hline CO & $\mathrm{g} / \mathrm{kWh}$ & $+/-1$ & $<8$ & $<4$ \\
\hline HC & $\mathrm{g} / \mathrm{kWh}$ & $+/-0.1$ & $<0.8$ & $<0.4$ \\
\hline COV & $\%$ & $+/-0.5$ & 3 & 3 \\
\hline Noise & $\mathrm{dB}$ & $+/-1$ & 85 & 89 \\
\hline
\end{tabular}
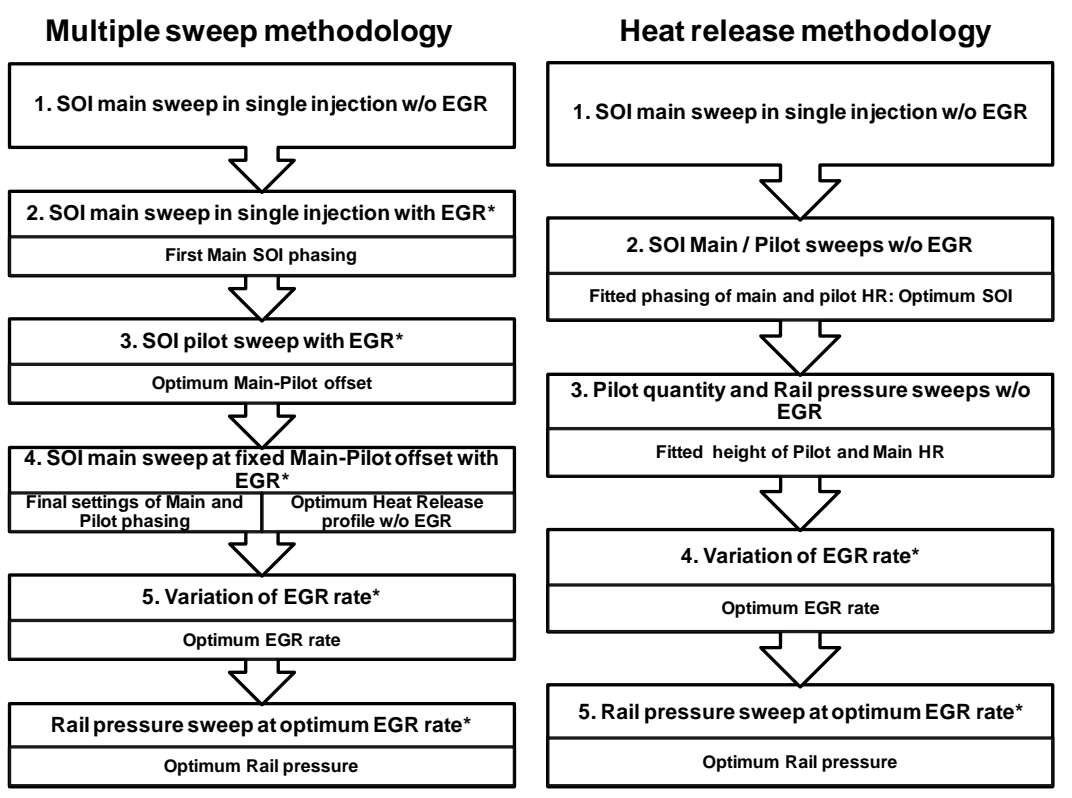

228 Figure 4: Overview of the optimization methodologies (*) optimum levels were determined in agreement with the target and constraints described in Table 3 


\subsection{NOx - PM tradeoff characterization}

231 To characterize the NOx-PM tradeoff, a quantified evaluation developed. Based on the NOx and PM 232 emissions measured during the final EGR sweep, exponential curves representing PM emissions as a 233 function of NOx (Figure 5) were fitted according to the following equation: $P M(g / k W h)=$ $234 A(i, j) \exp (B(i, j) / N O x(g / k W h))$, where A and B are fitting coefficients determined for the fuel $\mathrm{i}$ and 235 operation point $\mathrm{j}$. The correlation coefficients are above 0.95 for all matrix fuels optimized at different

236 speed-load conditions. The integral of the curves $\left(\mathrm{C}_{\mathrm{PM}}\right)$, calculated over a determined NOx range, allowed 237 the characterization of the NOx-PM tradeoff. Fuels having a better NOx-PM tradeoff would have a lower 238 level of PM integral (or cumulated particulates) over the integration domain. The robustness of this 239 evaluation was checked through a variation of the integration limits. This method for NOx-PM tradeoff 240 characterization aims to complete the more conventional optimum selection and point-to-point 241 comparison. The latter may not be representative of the overall fuel behavior and may not be indicative of 242 a fuel's sensitivity to small variation in engine settings, especially intake $\mathrm{O}_{2}$ concentration. This method is 243 usually poorly discriminating in the case of small differences.

\section{$244 \quad 3 \quad$ Results}

\section{$245 \quad 3.1 \quad$ Fuel matrix evaluation}

246 This section presents the results of the fuel matrix evaluation. To highlight the main fuel effect observed, 247 only matrix fuels composed of binary mixtures with a significant percentage of light gasoline and 248 kerosene streams are presented. Namely, Fuels 2, a diesel/kerosene blend and Fuels 5, 6, 10 and 12, which 249 are gasoline/diesel blends. Fuel 4 composed of 100\% HSRD was the reference fuel. Fuels are compared 250 on engine conditions EP1 and EP2. Figure 5 illustrates the comparison of the NOx-PM tradeoff and 251 cumulated particulates $\left(\mathrm{C}_{\mathrm{PM}}\right)$ over the NOx optimum range, i.e. from 0.7 to $1.5 \mathrm{~g} / \mathrm{kW} . \mathrm{h}$ and from 1 to 2 $252 \mathrm{~g} / \mathrm{kW} . \mathrm{h}$ on EP1 and EP2, respectively (Appendix C). To evaluate the robustness of this approach, the 253 limits of the NOx range were varied by $+/-0.5 \mathrm{~g} / \mathrm{kW} . \mathrm{h}$, and results show negligible variation of the main 
254 trends discussed hereafter. Moreover, optimum results summarized in Figure 6 are discussed to illustrate 255 the variation of fuel consumption and other regulated pollutants with respect to streams composition. 256 Engine results synthesis using the entire fuel matrix is summarized in Appendix C.

\section{Effect of the addition of Hydrotreated Straight Run Gasoline (HSRG) to Diesel}

258 On EP1, the addition of 50\% HSRG to both diesel streams (HSRD or HCKLD, in Fuel 6 and Fuel 5,

259 respectively) allows over 5 times lower $\mathrm{C}_{\mathrm{PM}}$ compared with reference diesel Fuel 4 . Through the 260 combination of fuel's higher volatility and increased ignition delay, HSRG addition shifts the combustion 261 towards the lower temperature range, thus reducing the NOx emissions. The decrease of PM emissions 262 may be associated with the fuel composition through lower fractions of aromatics and soot precursors 263 especially in Fuel 5, in agreement with the results of Weall et al. investigating gasoline-diesel blends [30].

264 Similar conclusions were obtained by Han et al. [17], [16] showing that the addition of gasoline up to $26540 \%$ vol allowed the simultaneous reduction of NOx and soot emissions. Optimum results comparison 266 (Figure 6) shows a reduction in fuel consumption and $\mathrm{HC}$ emissions (5\% and 25\%, respectively). 267 However, carbon monoxide increased by $30 \%$ and $85 \%$, for Fuel 5 and Fuel 6, respectively compared with 268 Fuel 4. Lower fuel consumption can be associated with the shorter combustion duration (CA90-CA10 is 269 half of that of diesel fuel), while the CO increase is mainly due to lower combustion efficiency typical of 270 low cetane number fuels especially at high EGR rates [33], usually due to over-mixing leading to fuel-lean 271 regions acting as carbon monoxide sources [14]. At the higher engine load of EP2, Fuels 5 and 6 present 272 similar trends and NOx-PM tradeoff is comparable to Fuel 4. 

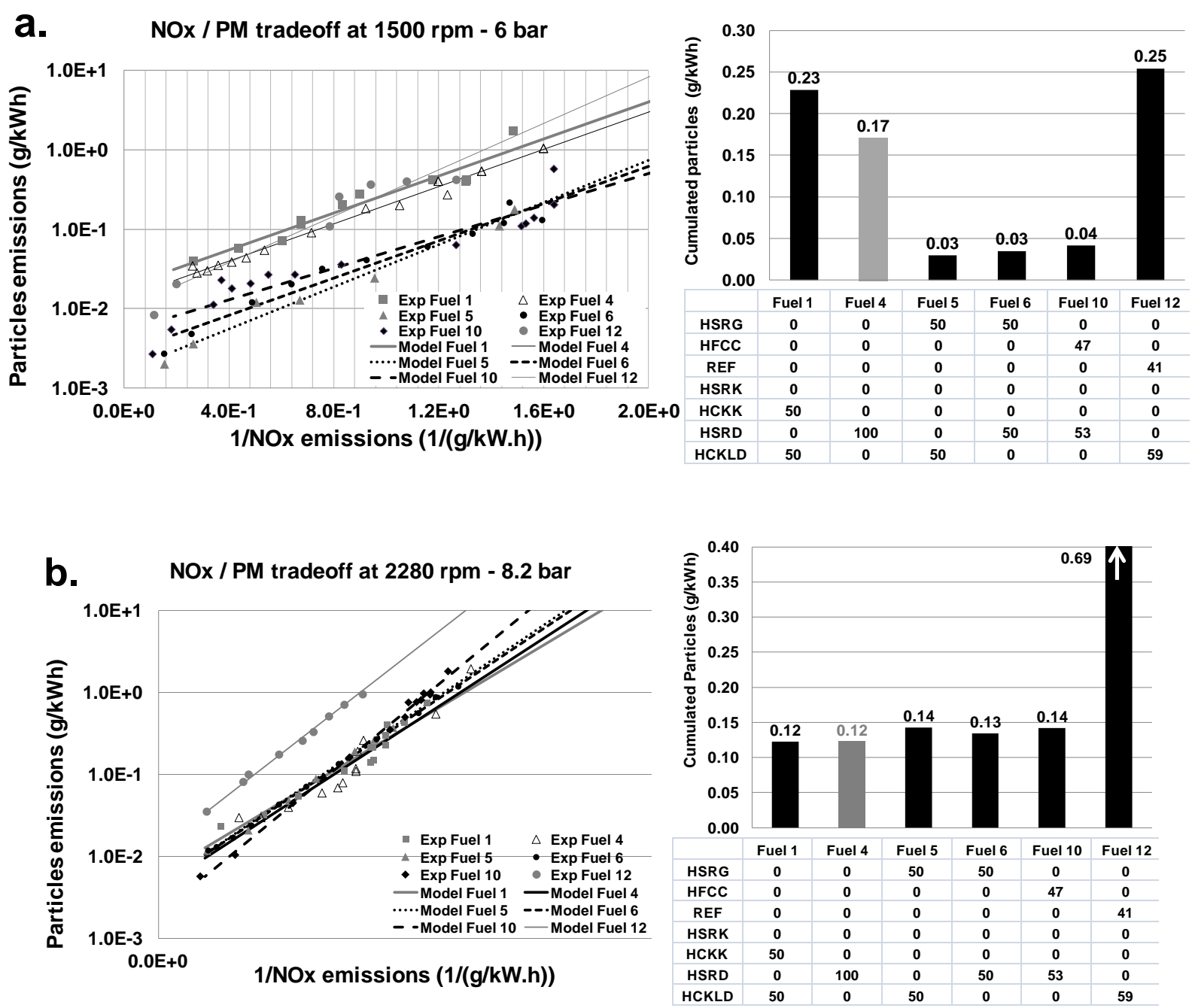

Figure 5: NOx-PM tradeoff during EGR sweeps (experiment and model) for several matrix fuels, CPM

278 This result is closely related to fuel characteristics. Later SOI, applied for diesel fuel allows for shifting

279 the combustion towards the lower temperature range, whereas, the EGR rate is limited by the soot

280 constraint. In the case of gasoline/diesel blends (Fuels 5 and 6), SOI is limited by stability, NOx emissions

281 are lowered through the higher EGR rate possible by virtue of their low sooting tendency. Both strategies

282 lead to a similar NOx-PM tradeoff, however, Fuels 5 and 6 present the advantage of reduced fuel

283 consumption, through better combustion phasing and shorter combustion duration favored by better air

284 fuel mixing. 

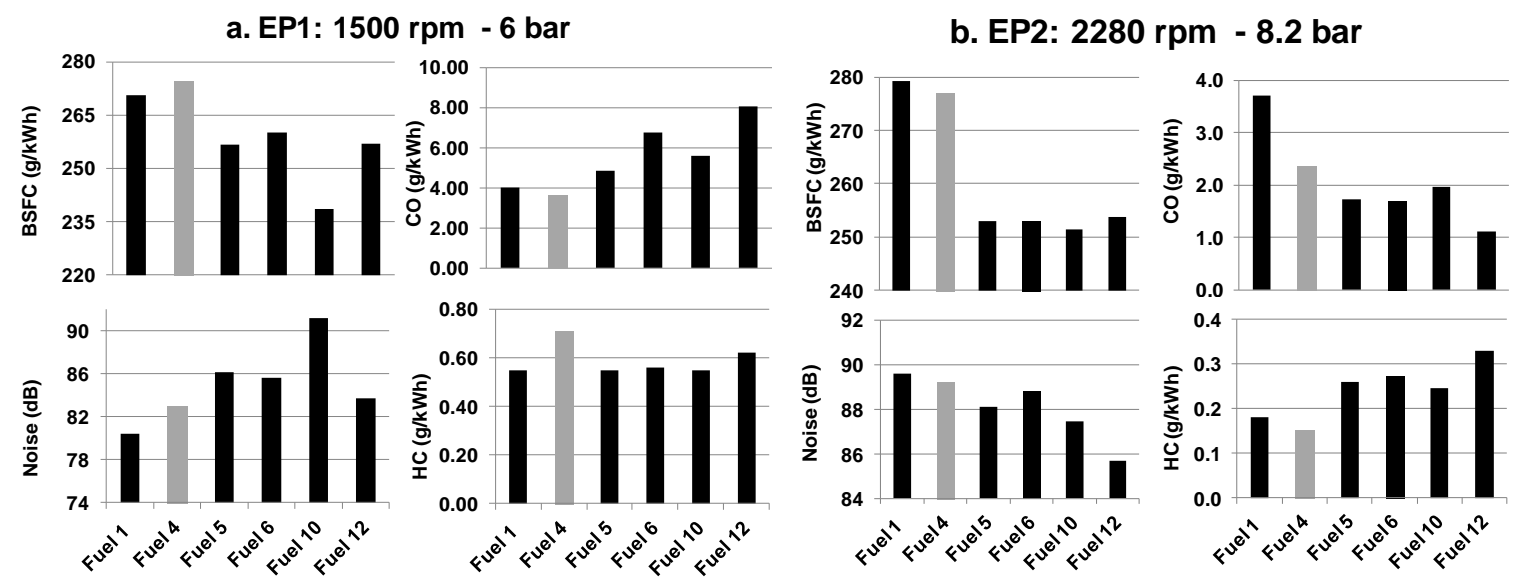

Figure 6: Optimized engine outputs of several matrix fuels tested at two engine conditions: a) EP 1: 1500 rpm-6bar and b) EP2: 2280rpm-8.2 bar

\section{Effect of the addition of Hydrotreated Fluid Catalytic Cracking (HFCC) to Diesel}

HFCC addition to HSRD studied in Fuel 10 reduces by over 4 times $\mathrm{C}_{\mathrm{PM}}$ compared with HSRD. Low CN

contributes to increase the autoignition delay, shifting the combustion towards lower temperatures which

reduces NOx emissions. Additionally, the high volatility reduces the formation fuel rich areas and high

olefin content ensures a high reaction rate [34] thus reducing PM emissions. Both effects allow for achieving very good NOx-PM tradeoff at EP1. Optimum results at EP1 (Figure 6), illustrate 13\% lower fuel consumption and 23\% lower $\mathrm{HC}$ emissions compared with Fuel 4. In fact, the higher rate of combustion of the olefin-rich HFCC stream reduces the combustion duration and favors thermal efficiency. $\mathrm{CO}$ emissions increase by over $45 \%$ comparably with the HSRG effect (Fuel 6). We note that noise level was very high $(91 \mathrm{~dB})$ and could not be reduced with the settings variation, most likely due to the increased autoignition delay and mixture-controlled combustion. At higher load at EP2, Fuel 10 presents roughly similar results to Fuel 4 in terms of NOx-PM tradeoff, CO, HC and noise. However, a better fuel economy is achieved mainly due to better phasing and shorter combustion promoted by better mixing. 
305 The addition of around $40 \%$ REF to HCKLD in Fuel 12 leads to a significant degradation in the $\mathrm{C}_{\mathrm{PM}}$ 306 performance (8 times higher than the HSRG/HCKLD mixture and 50\% higher than reference diesel). This 307 trend can be attributed to the low $\mathrm{CN}$ of Fuel 12 and the low combustion stability that limits EGR 308 capacity. Both contribute to NOx formation through increased mixture-controlled high temperature 309 combustion, thus, confirming a negative effect of excessive ignition delay on exhaust emissions observed 310 by other groups [35]. Moreover, the higher aromatic fraction provided by the REF stream contributes to an 311 increase in the soot precursors and can also play a role in increasing NOx formation [24]. Contrary to the 312 HSRG and HFCC effect on NOx-PM, which drops off at higher load, the negative effect of REF addition 313 to diesel is more pronounced at higher load (Figure 5). A fair linear relationship between $\mathrm{C}_{\mathrm{PM}}$ and $\mathrm{REF}$ 314 volume fraction is obtained. Optimum results show a similar positive trend on fuel consumption on EP1 315 and EP2 and CO emissions increase on EP1 in agreement with the other gasoline streams.

\section{Effect of the addition of Hydrocracked Kerosene (HCKK) to Diesel}

317 The addition of HCKK kerosene stream to HCKLD in Fuel 1 leads to an increase in $\mathrm{C}_{\mathrm{PM}}$ by over 7 times 318 compared with HSRG in the same proportion (Fuel 5) at EP1. Its lower volatility and higher cetane 319 number reduces the mixing efficiency and favors the formation of fuel-rich areas which increases the 320 sooting tendency. The fuel chemistry can also contribute to a NOx rise through lower paraffin and higher 321 naphthenes fractions. The NOx relationship to the molecular structure of alkanes studied in literature 322 shows higher NOx tendency for cyclic paraffins compared to normal and branched ones [24][36]. At 323 higher load, the addition of HCKK has a relatively small impact on NOx-PM tradeoff. Optimum results 324 presented in Figure 6 illustrate higher fuel consumption at EP1 and EP2, and reduced CO emissions at 325 EP1 which confirms the previous hypothesis. Overall, we observe that kerosene/diesel blends behave 326 similarly to diesel streams in terms of engine efficiency and regulated pollutants. 
329 The analysis of engine results allows a first evaluation of both the direct and synergistic effects of refinery 330 streams on engine outputs. The results suggest a significant impact of gasoline streams composition on the $331 \mathrm{NOx} / \mathrm{PM} /$ fuel economy trade off. REF addition to diesel streams appears to degrade the NOx-PM tradeoff 332 at both engine loads. HSRG illustrates a good potential for simultaneously reducing NOx, PM and fuel 333 consumption with an acceptable increase of carbon monoxide at light load. The addition of olefins-rich 334 HFCC to HSRD diesel streams is also favorable for NOx / PM trade-off at light load. Finally, the HCKK 335 stream shows diesel-like behavior at light and high load, with rather degraded CO emissions. Results show 336 a sensitivity of the NOx-PM tradeoff to streams composition which varies with the engine load: lower 337 load engine conditions, characterized by higher homogeneity, are more sensitive to the fuel properties than 338 higher load conditions.

\subsection{Modeling of engine outputs and optimization function of the refinery} streams composition

341 Linear models with no interaction were built linking optimum results obtained at EP1 and EP2 to the 342 refinery streams' volume fractions. Figure 7 presents predicted and experimental results for several engine 343 outputs of matrix fuels (Fuels 1-12) along with the validation fuel (Fuel 13). Results are normalized from 3440 to 1 at the scale of all the experimental results. Details of the model coefficients and statistical data are 345 summarized in Appendix D.

346 Fuel consumption has a determination coefficient $\left(\mathrm{R}^{2}\right)$ above 0.97 for both EP 1 and EP2; Results of Fuel 34713 overestimate fuel consumption by $8 \%$ for EP1 and are fairly predictive for EP2. NOx and PM models 348 have low determination coefficients $(0.78$ and 0.62 respectively for EP1 and 0.93 and 0.45 , respectively 349 for EP2). The poor performance of the PM model at EP2 can be associated with the quasi-equity of 350 particulate emissions at the optimum point for most fuels (Appendix C). The models accurately predict 351 EP2 NOx level for Fuel 13 and within twice the standard deviation interval $(\sigma)$ for EP1. PM emissions are 
352 within twice $(\sigma)$ at both operating points. The quality of the $\mathrm{CO}$ and $\mathrm{HC}$ emissions models was good for 353 EP2 and fair for EP1 (Appendix D). Fuel 13 results were fairly predicted for both. Finally, the model of $354 \mathrm{C}_{\mathrm{PM}}$, was fair on EP1 $\left(\mathrm{R}^{2}=0.65\right)$ and good on $\mathrm{EP} 2\left(\mathrm{R}^{2}=0.93\right)$. The prediction of Fuel 13 level was fair only 355 for EP2 and poor for EP1.
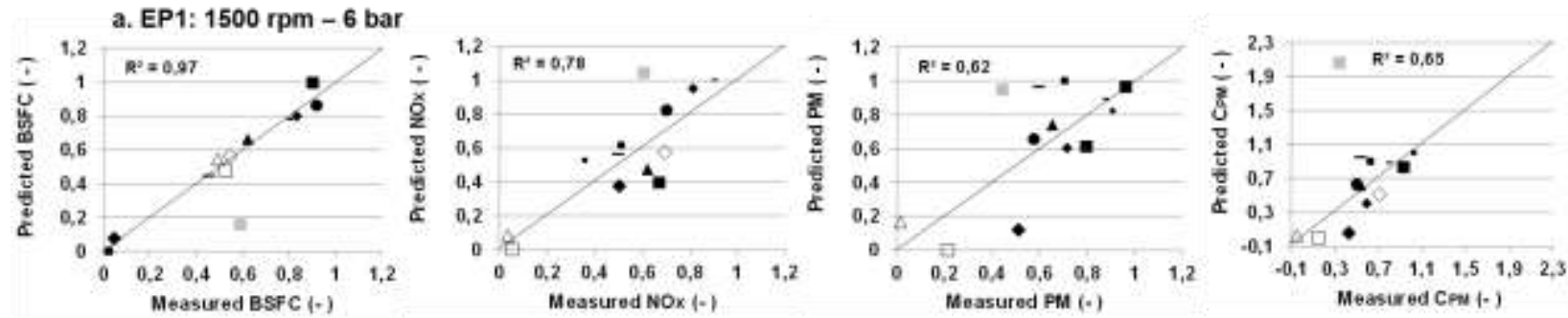

b. EP2: $2280 \mathrm{rpm}-8,2$ bar
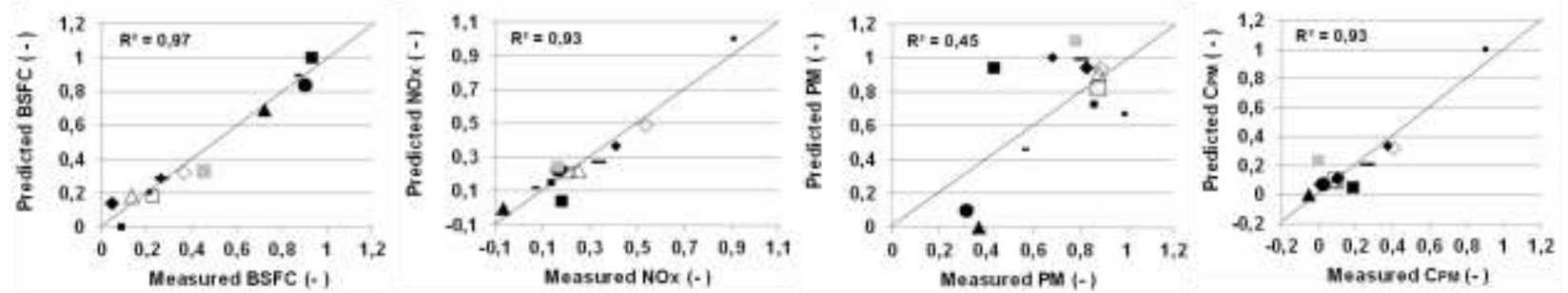

Figure 7: Modeling of the engine outputs based on optimum results at EP1 (1500rpm - 6 bar) and EP2

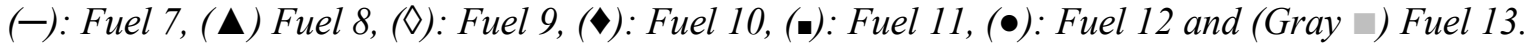

Figure 8 presents the normalized correlation coefficients. They illustrate the contribution of the different refinery streams to fuel consumption, NOx and particulates on EP1 and EP2. Fuel consumption coefficients are similar for EP1 and EP2 where diesel and kerosene streams have higher coefficients compared with gasoline streams and in agreement with the previous analysis. At light load, HSRG and HFCC streams reduces heat rejection through lower combustion temperature, while at mid load, they induce later and higher temperature premixed combustion, thus increasing the combustion efficiency (Figure 6). NOx coefficients vary significantly between EP1 and EP2. EP 1 presents a higher sensitivity to 

streams composition. The lowest coefficients are associated with HSRG and REF, then HFCC, while 369 diesel and kerosene streams are more similar, confirming previous conclusions. At higher load, HFCC and 370 HSRG streams' coefficients become higher than both kerosene and diesel, although of a similar 371 magnitude. REF has the worst effect on NOx emissions, three times higher than standard diesel and over 372 twice as high as the other gasoline streams. PM coefficients are lower for gasoline streams HSRG and 373 HFCC at light load and tend to increase at mid load. Only REF presented high PM coefficients for both 374 EP1 and EP2. HSRD and kerosene streams present a good tradeoff with average levels at EP1 and EP2. 375 The coefficients of the $\boldsymbol{C}_{\boldsymbol{P M}}$ model, in agreement with the previous analysis of NOx and PM coefficients, 376 underline the negative effect of REF stream on EP1 and more significantly on EP2, and the suitability of 377 gasoline streams HSRG and HFCC at light load with low coefficients and kerosene and diesel streams at 378 mid load.

379 To summarize, modeling of the engine outputs allows qualitative representation of the main streams 380 effects described in section 2.1. The models' accuracy was fair for several engine outputs over the tested 381 conditions, however not sufficiently predictive for the results of the validation fuel. This may be 382 associated to the relatively low number of fuels used to build the model. Besides, the model did not take 383 into account streams' interactions, that may have an influence as well. Therefore, two approaches were 384 evaluated, for fuel optimization, first, through the minimization of pollutants (NOx and PM trade off), 385 then through a comparative evaluation of the optimized fuel with matrix fuels. 
a. EP1: $1500 \mathrm{rpm}$ - 6 bar

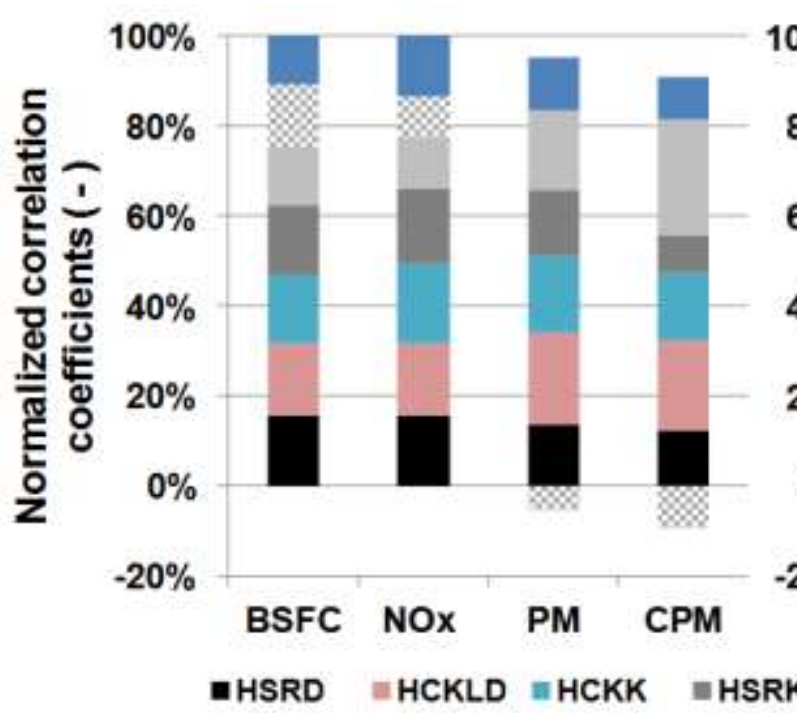

b. EP2: $2280 \mathrm{rpm}-8.2$ bar

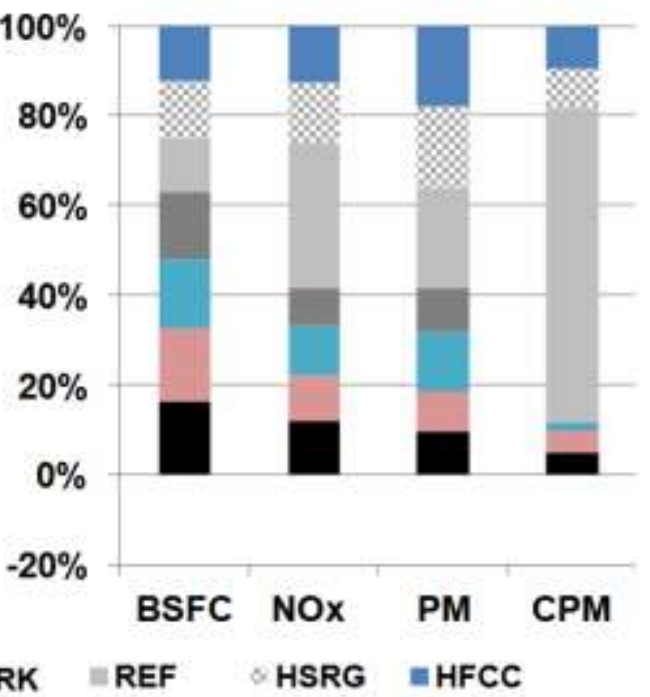

Figure 8: Normalized correlation coefficient of the linear model for a. EP 1 and b. EP 2 function of the

389 Based on the developed models, an optimization was carried out, aimed at proposing a streams composition allowing for the best NOx-PM tradeoff through the minimization of $\mathrm{C}_{\mathrm{PM}}$ criterion averaged on EP1 and EP2 $C_{P M}=\frac{C_{P M}(E P 1)+C_{P M}(E P 2)}{2}$. The optimization was carried out under the same constraints 392 on EP1 and EP2 for PM, CO, HC and stability adopted for the matrix fuel evaluation methodology (Table 393 3). Interestingly, the optimum composition is one of the matrix fuels tested: Fuel 6, a diesel/gasoline blend 394 composed of 50\%v HSRD and 50\%v HSRG, in good agreement with the ranking of the fuels according to 395 average $\mathrm{C}_{\mathrm{PM}}$ displayed in Figure 9. This fuel allows, at light load, a drastic reduction in NOx emissions 396 and a low sooting tendency, and a fairly good behavior at mid load. 


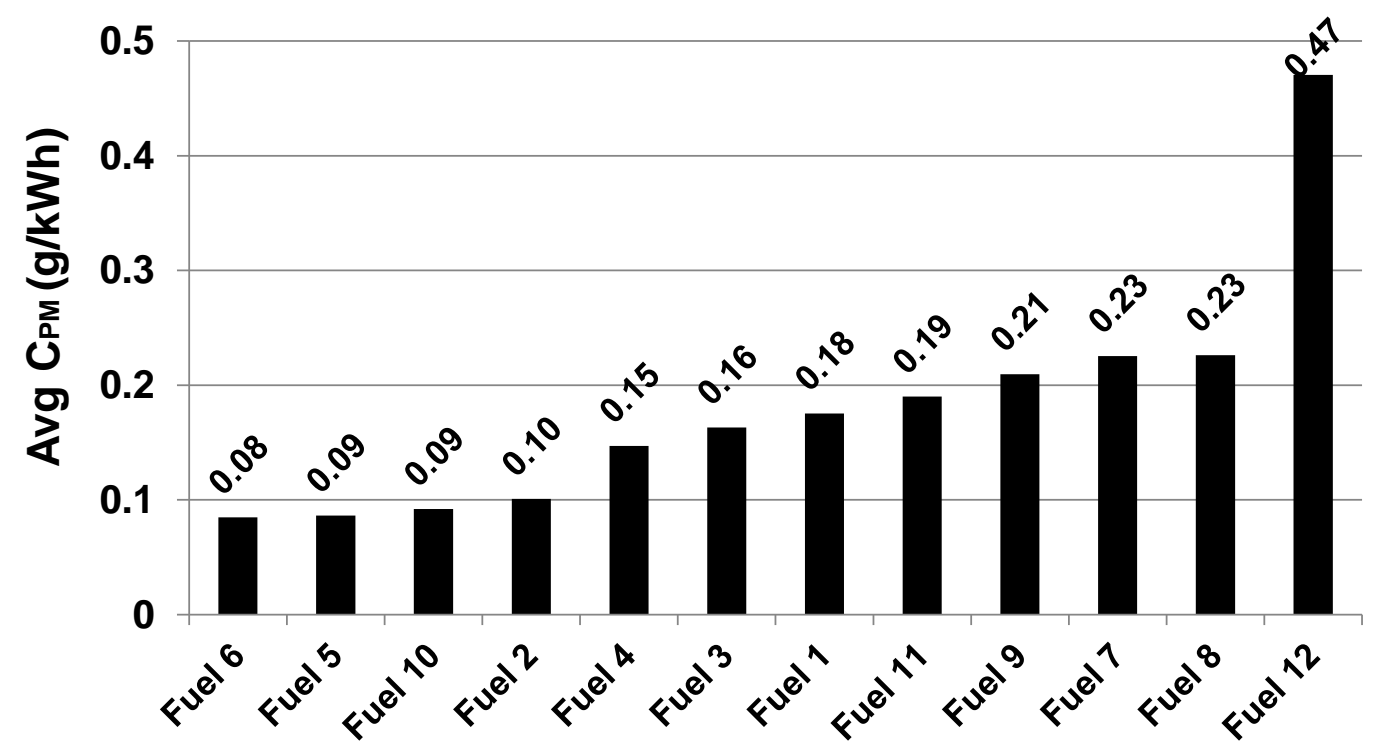

\section{Conclusions}

400 In this study, we propose an original methodology to optimize the fuel formulation for compression

401 ignition light-duty engines, to achieve lower pollutants emissions and higher engine efficiency based on a

402 DoE approach. Seven refinery streams representative of gasoline, kerosene and diesel cuts are used. A D-

403 Optimal mixture design was applied to build, a 12-run, 7-factor fuel matrix. Fuels were thoroughly 404 optimized on light and mid load engine points representative of typical vehicle running conditions. The 405 results show a high sensitivity of the engine efficiency and pollutants emissions to streams composition.

406 Optimal fuel requirements varied as a function of the engine operating point. At light load, the addition of 407 up to $50 \%$ gasoline streams (mainly HSRG) to diesel streams demonstrates a better potential to achieve 408 simultaneously low NOx and PM emissions and an overall good engine performance. Reformate, a highly 409 aromatic gasoline stream, did not offer an advantage at any of the tested conditions due to high particulate 410 emissions. The two kerosene streams evaluated in this work performed similarly to diesel streams in terms 411 of engine efficiency and pollutants emissions. A compromise fuel is proposed composed of $50 \% \mathrm{vHSRG}$ 
412 and 50\%vHSRD that allows halving of NOx and PM emissions and reducing of fuel consumption by

$4135 \%$ wt compared to reference diesel HSRD.

414 This study allowed to put forward an interesting potential of using gasoline and kerosene streams in diesel

415 fuels on a commercial light-duty diesel engine (PSA DV6D). The optimization methodology was based on

416 reduced number of parameters and interactions. A more elaborated engine calibration would be necessary

417 to confirm the observed trends on larger range of operating conditions. Besides, the upgrading of the

418 engine hardware (especially, in terms of boost pressure and combustion chamber design) may allow to

419 further explore the full potential of these streams in terms of engine performance and emissions.

\section{Acknowledgement}

421 Authors acknowledge the valuable support of Saudi Aramco to this research work and would like to thank

422 Romain CHERBLAND and Yoan LEMONNIER from IFP Energies Nouvelles for conducting the engine

423 experiments and Frederic NICOLAS from IFP Energies Nouvelles for engine calibration support. 


\section{References}

425 [1] "EU Transport in Figures - Statistical Pocketbook 2014," European Commission, Tech. Rep., 4262014.

427 [2] A. Capros, N. Devitan, and T. D. et al, "EU Energy, Transport and GHG emissions Trends to 428 2050, Reference scenario 2013,” European commission, Tech. Rep., 2013.

429 [3] R. H. Stanglmaier and C. E. Roberts, "Homogeneous charge compression ignition (HCCI): 430 benefits, compromises, and future engine applications,” SAE Technical Paper, Tech. Rep., 1999.

431 [4] M. Christensen, A. Hultqvist, and B. Johansson, "Demonstrating the Multi Fuel Capability of a 432 Homogeneous Charge Compression Ignition Engine with Variable Compression Ratio," SAE Technical 433 Paper, vol. 1999-01-3679, 1999.

434 [5] L. Pesant and L. Forti, "IFP International consortium Effects of fuel and additives on diesel HCCI 435 engines, 4th year, final report,” IFPEN, Tech. Rep., 2008.

436 [6] M. Muether, M. Lamping, A. Kolbeck, R. F. Cracknell, D. J. Rickeard, and K. D. Rose, 437 “Advanced Combustion for Low Emissions and High Efficiency Part 1: Impact of Engine Hardware on 438 HCCI Combustion,” SAE Technical Paper, vol. 2008-01-2405, 2008.

439 [7] C. Noehre, M. Andersson, B. Johansson, and A. Hultqvist, "Characterization of partially premixed 440 combustion,” SAE Technical Paper, Tech. Rep., 2006.

441 [8] G. T. Kalghatgi, P. Risberg, and H.-E. Angstrom, "Partially Pre-Mixed Auto-Ignition of Gasoline 442 to Attain Low Smoke and Low NOx at High Load in a Compression Ignition Engine and Comparison with 443 a Diesel Fuel,” SAE Technical Paper, vol. 2007-01-0006, 2007. 
444 [9] A. Warey, J.-P. Hardy, M. Hennequin, M. Tatur, D. Tomazic, and W. Cannella, "Fuel Effects on 445 Low Temperature Combustion in a Light-Duty Diesel Engine,” SAE Technical Paper, vol. 2010-01-1122, 4462010.

447 [10] T. Zannis and D. Hountalas, "Effect of fuel aromatic content and structure on direct-injection 448 diesel engine pollutant emissions," Journal of the Energy Institute, vol. 77, no. 511, pp. 16-25, 2004.

449 [11] R. F. Cracknell, D. J. Rickeard, J. Ariztegui, K. D. Rose, M. Muether, M. Lamping, and 450 A. Kolbeck, "Advanced Combustion for Low Emissions and High Efficiency Part 2: Impact of Fuel 451 Properties on HCCI Combustion,” SAE Technical Paper, vol. 2008-01-2404, 2008.

452 [12] A. S. E. Cheng, B. T. Fisher, G. C. Martin, and C. J. Mueller, "Effects of Fuel Volatility on Early 453 Direct-Injection, Low-Temperature Combustion in an Optical Diesel Engine," Energy \& Fuels, vol. 24, 454 no. 3, pp. 1538-1551, 2010. [Online]. Available: http://pubs.acs.org/doi/abs/10.1021/ef9011142

455 [13] P. Miles, "Sources and mitigation of $\mathrm{CO}$ and UHC emissions in low-temperature diesel 456 combustion regimes: Insights obtained via homogeneous reactor modeling," in 13th Diesel Engine 457 Efficiency and Emissions Research Conference, August 13-16, Detroit, Michigan, 2007.

458 [14] M. P. Musculus, T. Lachaux, L. M. Pickett, and C. A. Idicheria, "End-of-injection over-mixing 459 and unburned hydrocarbon emissions in low-temperature-combustion diesel engines," SAE Technical 460 Paper, Tech. Rep., 2007.

461 [15] S. M. Aceves, D. L. Flowers, C. K. Westbrook, J. R. Smith, W. Pitz, R. Dibble, M. Christensen, 462 and B. Johansson, "A multi-zone model for prediction of HCCI combustion and emissions," SAE 463 Technical paper, Tech. Rep., 2000.

464 [16] D. Han, A. M. Ickes, S. V. Bohac, Z. Huang, and D. N. Assanis, "Premixed low-temperature 465 combustion of blends of diesel and gasoline in a high speed compression ignition engine," Proceedings of 
the Combustion Institute, vol. 33, no. 2, pp. 3039 - 3046, 2011. [Online]. Available: http://-

467 www.sciencedirect.com/science/article/pii/S1540748910003081

468 [17] D. Han, A. M. Ickes, D. N. Assanis, Z. Huang, and S. V. Bohac, "Attainment and Load Extension 469 of High-Efficiency Premixed Low-Temperature Combustion with Dieseline in a Compression Ignition 470 Engine," Energy \& Fuels, vol. 24, no. 6, pp. 3517-3525, 2010. [Online]. Available: http://pubs.acs.org/471 doi/abs/10.1021/ef100269c

472 [18] P. Risberg, G. Kalghatgi, H.-E. Ångstrom, and F. Wåhlin, “Auto-ignition quality of diesel-like 473 fuels in HCCI engines,” SAE Technical Paper, Tech. Rep., 2005.

474 [19] P. Bergstrand, "Effects on combustion by using kerosene or MK1 diesel," SAE Technical Paper, 475 Tech. Rep., 2007.

476 [20] A. P. Singh and A. K. Agarwal, "Dieseline, Diesohol and Diesosene Fuelled HCCI Engine 477 Development," SAE Technical Paper, Tech. Rep., 2015.

478 [21] K. Nakakita, H. Ban, S. Takasu, Y. Hotta, K. Inagaki, W. Weissman, and J. T. Farrell, "Effect of 479 hydrocarbon molecular structure in diesel fuel on in-cylinder soot formation and exhaust emissions," SAE 480 Technical Paper, Tech. Rep., 2003.

481 [22] J. Song and K. O. Lee, "Fuel Property Impacts on diesel particulate morphology, nanostructures, 482 and NOx emissions," SAE Technical Paper, Tech. Rep., 2007.

483 [23] Y. Takatori, Y. Mandokoro, K. Akihama, K. Nakakita, Y. Tsukasaki, S. Iguchi, L. I. Yeh, and 484 A. M. Dean, "Effect of Hydrocarbon Molecular Structure on Diesel Exhaust Emissions Part 2: Effect of 485 Branched and Ring Structures of Paraffins on Benzene and Soot Formation," in SAE Technical Paper. 486 SAE International, 10 1998. [Online]. Available: http://dx.doi.org/10.4271/982495 
[24] F. Bachmaier, K. Eberius, and T. Just, "The formation of nitric oxide and the detection of HCN in premixed hydrocarbon-air flames at 1 atmosphere," Combustion Science and Technology, vol. 7, no. 2, pp. 77-84, 1973.

[25] S.-S. Kee, A. Mohammadi, Y. Kidoguchi, and K. Miwa, "Effects of Aromatic Hydrocarbons on

Fuel Decomposition and Oxidation Processes in Diesel Combustion," in SAE Technical Paper. SAE

[26] M. Al-Abdullah, G. Kalghatgi, and H. Babiker, "Flash points and volatility characteristics of gasoline/diesel blends," Fuel, vol. 153, pp. 67 - 69, 2015. [Online]. Available: http://Www.sciencedirect.com/science/article/pii/S0016236115002239

[27] M. Castagne, Y. Bentolila, F. Chaudoye, H. A., F. Nicolas, and D. Sinoquet, "Comparison of different calibration methods based on design of experiments," Oil \& Gas Science and Technology - Rev. IFP, vol. 63, no. 4, pp. 563-582, 2008. [Online]. Available: http://dx.doi.org/10.2516/ogst:2008029 Number, Volatility, and Total Aromatic Content on Highly- Dilute Low Temperature Diesel Combustion," SAE Technical Paper, vol. 2010-01-0337, 2010.

[30] A. Weall and N. Collings, "Investigation into Partially Premixed Combustion in a Light-Duty 504 Multi-Cylinder Diesel Engine Fuelled with a Mixture of Gasoline and Diesel," SAE Technical Paper, vol. $505 \quad 2007-01-4058,2007$. www.sciencedirect.com/science/article/pii/0009250984870098 
510 of Naphtha Fuel Achieving Both High Efficiency and Drivability with EURO6 Engine-Out NOx

511 Emission,” SAE International Journal of Engines, vol. 6, no. 1, pp. 101-119, 2013.

512 [33] Y. Jeihouni, S. Pischinger, L. Ruhkamp, and T. Koerfer, "Relationship between fuel properties 513 and sensitivity analysis of non-aromatic and aromatic fuels used in a single cylinder heavy duty diesel 514 engine,” SAE Technical Paper, Tech. Rep., 2011.

515 [34] L. Starck, B. Lecointe, L. Forti, and N. Jeuland, "Impact of fuel characteristics on $\{\mathrm{HCCI}\}$ 516 combustion: Performances and emissions," Fuel, vol. 89, no. 10, pp. 3069 - 3077, 2010. [Online].

517 Available: http://www.sciencedirect.com/science/article/pii/S001623611000253X

518 [35] K. Kitano, R. Nishiumi, Y. Tsukasaki, T. Tanaka, and M. Morinaga, "Effects of Fuel Properties 519 on Premixed Charge Compression Ignition Combustion in a Direct Injection Diesel Engine," SAE 520 Technical Papers, vol. 2003-01-1815, 05 2003. [Online]. Available: http://dx.doi.org/10.4271/2003-01$521 \quad 1815$

522 [36] L. J.C.Y. and M. P.C., "NOX as a function of fuel for C1-to-C16 hydrocarbons and methanol 523 burned in a high intensity, lean-premixed, combustion reactor." in WSS Meeting, Combustion Institute, 5241998.

525 [37] R. Lugo, V. Ebrahimian, C. Lefebvre, and C. e. a. Habchi, "A Compositional Representative Fuel 526 Model for Biofuels - Application to Diesel Engine Modelling," SAE Technical Paper, vol. 2010-01-2183, 5272010. 


\section{$528 \quad 7 \quad$ Appendices} \\ Appendix A: Main properties of the studied refinery streams}

\begin{tabular}{|c|c|c|c|c|c|c|c|c|c|}
\hline Analyses & Method & Unit & REF & HFCC & HSRG & HCKK & HSRK & HCKLD & HSRD \\
\hline Density at $15^{\circ} \mathrm{C}$ & ASTM D4052 & $\mathrm{kg} / \mathrm{m} 3$ & 868.4 & 691.9 & 741.1 & 812.2 & 787.7 & 818.7 & 836.6 \\
\hline Viscosity $40^{\circ} \mathrm{C}$ & EN ISO 3104 & $\mathrm{~mm}^{2} / \mathrm{s}$ & 0.5958 & 0.36 & 0.5685 & 1.342 & 1.122 & 2.634 & 3.297 \\
\hline LHV & ASTM D240 & $\mathrm{MJ} / \mathbf{k g}$ & 41.03 & 44.46 & 44.29 & 43.89 & 40.73 & 43.57 & 42.57 \\
\hline Sulfur & $\begin{array}{l}\text { NF EN ISO } \\
20846 \\
\end{array}$ & $\mathrm{mg} / \mathbf{k g}$ & $<0.5$ & 5.7 & $<0.5$ & $<0.5$ & 221 & $<0.5$ & 1.5 \\
\hline CN (CFR) & ASTM D613 & - & $6.1^{*}$ & $16.5^{*}$ & 34.8 & 45.4 & 49.0 & 54.9 & 51.3 \\
\hline H/C/N (IFPEN) & CG & & & & & & & & \\
\hline C & & $\%$ wt & 90.5 & 85.9 & 85.4 & 86.0 & 85.8 & 85.8 & 86.4 \\
\hline $\mathbf{H}$ & & $\% \mathbf{w t}$ & 9.5 & 14.1 & 14.6 & 13.8 & 14.1 & 14.0 & 13.6 \\
\hline $\mathbf{N}$ & & $\% \mathbf{w t}$ & & & & & 0.09 & 0.12 & \\
\hline 0 & & $\% \mathbf{w t}$ & & & & 0.11 & & 0.11 & \\
\hline Total & & $\% \mathbf{w t}$ & 100.0 & 100.0 & 100.0 & 100.0 & 100.0 & 100.0 & 100.0 \\
\hline $\mathrm{H} / \mathrm{C}$ & & - & 1.255 & 1.970 & 2.056 & 1.930 & 1.971 & 1.958 & 1.889 \\
\hline Composition & GCxGC & & 8535 & 8533 & 8534 & 8532 & 8531 & 8536 & 8537 \\
\hline Paraffins & & $\%$ wt & 2.15 & 33.1 & 59.0 & 36.3 & 57.2 & 43.4 & 29.9 \\
\hline Naphthenes & & $\% \mathbf{w t}$ & 0.14 & 7.0 & 27 & 43 & 18.5 & 40.2 & 25 \\
\hline Olefins & & $\% \mathbf{w t}$ & 0.17 & 45.0 & 0 & 0 & 0 & 0 & 0 \\
\hline Aromatics & & $\% \mathbf{w t}$ & 97.5 & 14.8 & 13.9 & 20.7 & 24.3 & 16.4 & 45.3 \\
\hline Monoaromatics & & $\% \mathbf{w t}$ & 96.7 & 14.8 & 13.9 & 19.5 & 23.3 & 14.7 & 41.7 \\
\hline Polyaromatics & & $\% \mathbf{w t}$ & 0.8 & 0.0 & 0.0 & 1.2 & 1 & 1.7 & 3.6 \\
\hline Distillation & EN ISO 3405 & & & & & & & & \\
\hline 0 & & ${ }^{\circ} \mathrm{C}$ & 105.8 & 30.4 & 81 & 166.9 & 149.9 & 123.9 & 187.9 \\
\hline 5 & & ${ }^{\circ} \mathrm{C}$ & 119.5 & 36.9 & 98 & 184.6 & 165.8 & 207.4 & 201.3 \\
\hline 10 & & ${ }^{\circ} \mathrm{C}$ & 121.5 & 39 & 102.1 & 190.4 & 169.7 & 229.8 & 206.7 \\
\hline 15 & & & 122.9 & 40.3 & 104.9 & 193.4 & 173 & 241.1 & 213.4 \\
\hline 20 & & ${ }^{\circ} \mathrm{C}$ & 124.1 & 41.4 & 107.6 & 196.2 & 175.6 & 247.6 & 220.8 \\
\hline 30 & & ${ }^{\circ} \mathrm{C}$ & 126.2 & 43.7 & 112.4 & 200.7 & 181.1 & 257.7 & 240.6 \\
\hline 40 & & ${ }^{\circ} \mathrm{C}$ & 128.7 & 46.3 & 117 & 204.3 & 186.2 & 264.9 & 268.5 \\
\hline 50 & & ${ }^{\circ} \mathrm{C}$ & 131.6 & 49.6 & 122.9 & 207.5 & 191.5 & 271.7 & 296.7 \\
\hline 60 & & ${ }^{\circ} \mathrm{C}$ & 135.1 & 54.1 & 129.1 & 210.9 & 197.5 & 278.5 & 320.1 \\
\hline 70 & & ${ }^{\circ} \mathrm{C}$ & 140.2 & 61.1 & 135 & 214.5 & 205.4 & 284.7 & 344.7 \\
\hline 80 & & ${ }^{\circ} \mathrm{C}$ & 146.8 & 72.8 & 143 & 219.4 & 215.9 & 292.5 & 362.7 \\
\hline 90 & & ${ }^{\circ} \mathrm{C}$ & 156.7 & 88.9 & 152.7 & 226.4 & 231.6 & 304 & 373.6 \\
\hline 95 & & ${ }^{\circ} \mathrm{C}$ & 166.9 & 98.8 & 160.1 & 232 & 244.8 & 312.4 & 378.8 \\
\hline 100 & & ${ }^{\circ} \mathrm{C}$ & 198.7 & 115.4 & 171.2 & 243.4 & 267.8 & 320.2 & 381 \\
\hline Recovery at $250^{\circ} \mathrm{C}$ & & $\% \mathbf{v} / \mathbf{v}$ & & & & $>98$ & 96.3 & 22.6 & 33.9 \\
\hline
\end{tabular}




\begin{tabular}{|l|l|l|l|l|l|l|l|l|l|} 
Recovery at $350^{\circ} \mathbf{C}$ & & $\% \mathbf{v} / \mathbf{v}$ & & & & $>98$ & $>98$ & $>98$ & 72.3 \\
\hline Residue & & $\% \mathbf{v} / \mathbf{v}$ & 1.2 & 0.7 & 0.9 & & & & \\
\hline
\end{tabular}

$530 *$ The Cetane Number $(\mathrm{CN})$ of the streams is measured using a CFR engine, with 2 or 3

531 repeatability tests except for REF and HFCC that presented a very low reactivity. Their cetane

532 number was evaluated through blending methods with higher CN streams (namely, HSRK,

533 HSRD, HCKLD and HCKK).

534 Viscosity is measured using the standard test method (EN ISO 3104) at $40^{\circ} \mathrm{C}$ except HFCC (due

535 to high volatility; $\left.\mathrm{IBP}=30^{\circ} \mathrm{C}\right)$. The viscosity of $\mathrm{HFCC}$ is calculated using thermodynamic

$536 \quad$ Pedersen model [37].

537 Appendix B: Engine optimization methodology and targets

538 In this section, the detailed and simplified method for fuels optimization are evaluated on the same Fuel in

539 order to quantify the sensitivity to the fuels classification into cetane groups of the engine results. Fuel 5

540 having a central cetane number of 46.1 is tested using multiple sweeps method, and Iso-heat release

541 method in Group 1 and Group 2 (i.e. through the imitation of optimum heat release of Fuel 4 and Fuel 7,

542 respectively) at 3 different engine conditions. The comparison of optimum results shows almost $10 \%$

543 variation of BSFC on average. The amplitude of NOx and PM variation according to the optimization

544 methodology is on average 0.14 and $0.03 \mathrm{~g} / \mathrm{kW} . \mathrm{h}$, respectively. Optimization methodology impacts mostly

545 the noise level due to its tight relationship with the injection settings. As an initial evaluation of the

546 approach, the sensitivity of engine results to the methodology is taken into account as if it were an engine

547 measurement dispersion error. 


\begin{tabular}{|c|c|c|c|c|c|c|c|c|c|}
\hline \multicolumn{10}{|c|}{ EP $1: 1500 \mathrm{rpm}-6$ bar } \\
\hline \multirow{2}{*}{$\begin{array}{c}\text { Fuel } \\
\text { reference }\end{array}$} & BSFC & NOx & PM & $\mathrm{CO}$ & $\mathrm{HC}$ & $\mathrm{CO} 2$ & noise & stab & C PM \\
\hline & (g/kWh) & (g/kWh) & (g/kWh) & (g/kWh) & (g/kWh) & (g/kWh) & $\mathrm{dB}$ & $\%$ & $\mathrm{~g} / \mathrm{kWh}$ \\
\hline Fuel 1 & 271 & 1.48 & 0.12 & 4.00 & 0.55 & 848 & 80 & 0.85 & 0.228 \\
\hline Fuel 2 & 271 & 1.46 & 0.09 & 3.80 & 0.49 & 849 & 83 & 0.78 & 0.121 \\
\hline Fuel 3 & 281 & 1.22 & 0.12 & 7.10 & 0.59 & 878 & 82 & 0.96 & 0.217 \\
\hline Fuel 4 & 274 & 1.40 & 0.09 & 3.65 & 0.71 & 860 & 83 & 1.90 & 0.171 \\
\hline Fuel 5 & 257 & 1.05 & 0.02 & 4.86 & 0.55 & 799 & 86 & 0.82 & 0.030 \\
\hline Fuel 6 & 260 & 1.08 & 0.04 & 6.74 & 0.56 & 806 & 86 & 0.93 & 0.035 \\
\hline Fuel 7 & 255 & 1.29 & 0.12 & 4.29 & 0.64 & 802 & 83 & 1.21 & 0.242 \\
\hline Fuel 8 & 265 & 1.25 & 0.10 & 6.04 & 0.64 & 834 & 82 & 1.04 & 0.169 \\
\hline Fuel 9 & 261 & 1.29 & 0.09 & 5.07 & 0.50 & 824 & 83 & 2.14 & 0.143 \\
\hline Fuel 10 & 238 & 1.21 & 0.04 & 5.61 & 0.55 & 742 & 91 & 0.94 & 0.042 \\
\hline Fuel 11 & 235 & 1.31 & 0.13 & 4.22 & 0.58 & 733 & 89 & 1.09 & 0.231 \\
\hline Fuel 12 & 257 & 1.27 & 0.11 & 8.07 & 0.62 & 814 & 84 & 1.15 & 0.254 \\
\hline Fuel 13 & 242 & 1.50 & 0.12 & 1.39 & 0.26 & 761 & 85 & 1.09 & 0.492 \\
\hline
\end{tabular}

\begin{tabular}{|c|c|c|c|c|c|c|c|c|c|}
\hline \multicolumn{10}{|c|}{ EP 2 : $2280 \mathrm{rpm}-8.2 \mathrm{bar}$} \\
\hline \multirow{2}{*}{$\begin{array}{l}\text { Fuel } \\
\text { reference }\end{array}$} & BSFC & $\mathrm{NOx}$ & $\mathrm{PM}$ & $\mathrm{CO}$ & $\mathrm{HC}$ & $\mathrm{CO} 2$ & noise & stab & C PM \\
\hline & (g/kWh) & (g/kWh) & (g/kWh) & (g/kWh) & (g/kWh) & $(\mathrm{g} / \mathrm{kWh})$ & $\mathrm{dB}$ & $\%$ & $\mathrm{~g} / \mathrm{kWh}$ \\
\hline Fuel 1 & 279 & 1.15 & 0.15 & 3.72 & 0.18 & 876 & 90 & 0.69 & 0.123 \\
\hline Fuel 2 & 272 & 1.02 & 0.10 & 3.10 & 0.18 & 852 & 91 & 0.68 & 0.081 \\
\hline Fuel 3 & 283 & 1.06 & 0.20 & 4.05 & 0.17 & 891 & 89 & 0.74 & 0.109 \\
\hline Fuel 4 & 277 & 1.25 & 0.11 & 2.37 & 0.15 & 872 & 89 & 0.67 & 0.123 \\
\hline Fuel 5 & 253 & 1.26 & 0.19 & 1.73 & 0.26 & 792 & 88 & 0.69 & 0.143 \\
\hline Fuel 6 & 253 & 1.25 & 0.20 & 1.68 & 0.27 & 793 & 89 & 1.08 & 0.135 \\
\hline Fuel 7 & 257 & 1.30 & 0.21 & 1.57 & 0.30 & 811 & 88 & 0.65 & 0.209 \\
\hline Fuel 8 & 257 & 1.39 & 0.21 & 2.09 & 0.28 & 815 & 90 & 0.90 & 0.284 \\
\hline Fuel 9 & 258 & 1.52 & 0.20 & 1.30 & 0.24 & 822 & 88 & 0.90 & 0.276 \\
\hline Fuel 10 & 251 & 1.24 & 0.20 & 1.96 & 0.25 & 790 & 87 & 0.74 & 0.142 \\
\hline Fuel 11 & 246 & 1.18 & 0.18 & 1.62 & 0.20 & 774 & 88 & 1.17 & 0.149 \\
\hline Fuel 12 & 254 & 2.04 & 0.17 & 1.12 & 0.33 & 816 & 86 & 0.60 & 0.687 \\
\hline Fuel 13 & 258 & 1.27 & 0.22 & 1.79 & 0.20 & 812 & 87 & 0.62 & 0.223 \\
\hline
\end{tabular}


551 Appendix D: Synthesis of the models data of main engine outputs. Modeling was made on optimum

552 results of EP1 (1500rpm - 6 bar) and EP2 (2280 rpm-8.2 bar): Correlation coefficients, standard

553 deviations and determination coefficients

\begin{tabular}{|l|l|l|l|l|l|l|l|}
\hline \multirow{2}{*}{$\begin{array}{l}\text { Refinary } \\
\text { stream }\end{array}$} & \multicolumn{6}{|l}{ EP 1: 1500 rpm - 6 bar } \\
\cline { 2 - 8 } & $\mathbf{B S F C}$ & $\mathbf{N O x}$ & $\mathbf{P M}$ & $\mathbf{C O}$ & $\mathbf{H C}$ & Noise & Stability \\
\cline { 2 - 8 } & $\mathbf{g} / \mathbf{k W h}$ & $\mathbf{g} / \mathbf{k W h}$ & $\mathbf{g} / \mathbf{k W h}$ & $\mathbf{g} / \mathbf{k W h}$ & $\mathbf{g} / \mathbf{k W h}$ & $\mathbf{d B}$ & $\%$ \\
\hline HSRG & 238 & 0.77 & -0.03 & 6.41 & 0.48 & 89 & 0.46 \\
\hline HFCC & 192 & 1.17 & 0.07 & 4.52 & 0.50 & 98 & 0.73 \\
\hline REF & 228 & 0.96 & 0.11 & 12.71 & 0.68 & 85 & 1.95 \\
\hline HSRK & 269 & 1.44 & 0.09 & 2.98 & 0.51 & 81 & 0.49 \\
\hline HCKK & 263 & 1.50 & 0.10 & 2.23 & 0.43 & 80 & 1.66 \\
\hline HSRD & 277 & 1.35 & 0.08 & 4.72 & 0.68 & 83 & 1.74 \\
\hline HCKLD & 280 & 1.37 & 0.12 & 5.25 & 0.60 & 82 & 0.87 \\
\hline std dev & 3.24 & 0.09 & 0.03 & 1.28 & 0.06 & 1.25 & 0.36 \\
\hline $\mathbf{R}^{\mathbf{2}}$ & 0.97 & 0.78 & 0.62 & 0.64 & 0.54 & 0.93 & 0.68 \\
\hline
\end{tabular}

\begin{tabular}{|l|c|c|c|c|c|c|c|}
\hline \multirow{2}{*}{$\begin{array}{l}\text { Refinary } \\
\text { stream }\end{array}$} & \multicolumn{6}{|c|}{ EP 2: 2280 $\mathbf{~ r p m ~ - ~ 8 . 2 ~ b a r ~}$} \\
\cline { 2 - 8 } & $\mathbf{B S F C}$ & $\mathbf{N O x}$ & $\mathbf{P M}$ & $\mathbf{C O}$ & $\mathbf{H C}$ & Noise & Stability \\
\cline { 2 - 8 } & $\mathbf{g} / \mathbf{k W h}$ & $\mathbf{g} / \mathbf{k W h}$ & $\mathbf{g} / \mathbf{k W h}$ & $\mathbf{g} / \mathbf{k W h}$ & $\mathbf{g} / \mathbf{k W h}$ & $\mathbf{d B}$ & $\%$ \\
\hline HSRG & 223 & 1.4 & 0.3 & -0.1 & 0.4 & 88 & 1.1 \\
\hline HFCC & 213 & 1.3 & 0.3 & -0.1 & 0.3 & 86 & 1.2 \\
\hline REF & 207 & 3.3 & 0.3 & -3.0 & 0.6 & 81 & 0.8 \\
\hline HSRK & 262 & 0.9 & 0.1 & 2.9 & 0.2 & 93 & 0.9 \\
\hline HCKK & 269 & 1.1 & 0.2 & 2.7 & 0.2 & 90 & 0.9 \\
\hline HSRD & 279 & 1.2 & 0.1 & 2.8 & 0.2 & 89 & 0.7 \\
\hline HCKLD & 286 & 1.0 & 0.1 & 4.1 & 0.1 & 89 & 0.6 \\
\hline std dev & 3.03 & 0.10 & 0.04 & 0.55 & 0.03 & 0.33 & 0.22 \\
\hline $\mathbf{R}^{\mathbf{2}}$ & 0.97 & 0.93 & 0.45 & 0.84 & 0.90 & 0.97 & 0.31 \\
\hline
\end{tabular}

